\title{
Crustal structure of the eastern Piedmont and Atlantic coastal plain in North Carolina and Virginia, eastern North American margin
}

\author{
Wenbin Guo ${ }^{1 *}\left(\mathbb{D}\right.$, Shuai Zhao ${ }^{2}$, Fuyun Wang ${ }^{1}$, Zhuoxin Yang ${ }^{1}$, Shixu Jia ${ }^{1}$ and Zhi Liu
}

\begin{abstract}
The eastern North American rifted margin is a passive tectonic margin that has experienced Paleozoic ocean closure and Mesozoic continent rifting. To understand evolution of this continental margin, we modeled the two-dimensional P-wave and S-wave seismic velocity structure of the crust with a seismic wide-angle reflection/refraction profile located in North Carolina and Virginia. There is a seismic low-velocity zone (LVZ) at 10-12 km depth beneath the western segment of the profile. We infer the LVZ to be the base of a Paleozoic metasedimentary succession beneath the eastern Piedmont and westernmost coastal plain. The P-wave velocity and Poisson's ratio suggest a felsic composition for the upper and middle crust beneath the seismic profile, and an intermediate composition for the lower crust. Overall, the measured crustal velocities and the lateral homogeneity of the crust, especially the middle and lower crust, indicate that Laurentian middle and lower crust extends beneath the entire coastal plain. The lack of a basal crustal layer with a high seismic velocity indicates that no magmatic intrusions have underplated the eastern Piedmont and coastal plain. The comparison with South China Sea, which is a wide rift, and Kenya Rift, which is a narrow rift, indicates that eastern North American margin has the character of a narrow rift. We infer that narrow rifts and wide rifts may have similar crustal compositions, but show strong differences in crustal thickness and the distribution of basal crustal mafic intrusion. These differences may be related to differences in extensional rate during rifting.
\end{abstract}

Keywords: Seismic wide-angle reflection/refraction, P- and S-wave velocity, Crustal composition, Eastern North American margin, Rifted structure

\section{Introduction}

Continental rifts and their products, passive margins, define the majority of the Earth's coastline and are the expression of a fundamental process that continually reshapes our planet's surface. The eastern North American margin (ENAM) is the host to one of the world's longest rift system, the eastern North American rift system. This is one of the oldest intact passive margins and is a natural laboratory for studying passive margin development (Withjack et al. 2012). To understand the evolution of this rifted margin, seismic investigations of the crustal structure of this region began some 60 years ago

\footnotetext{
*Correspondence: gwb4133@hotmail.com

${ }^{1}$ Geophysical Exploration Center, China Earthquake Administration,

Zhengzhou, China

Full list of author information is available at the end of the article
}

(Bonini and Woollard. 1960; Hales et al. 1968; James et al. 1968). During the 1970s, the US Geological Survey conducted seismic reflection surveys along the US Atlantic continental margin (summarized in Pakiser and Mooney 1989) to determine the crustal structure and tectonic framework along the margin (Klitgord et al. 1988; Trehu et al. 1989; Glover and Klitgord 1995). Cook et al. (1979, 1981) interpret seismic reflection profiles in terms of thin-skinned tectonics in the southern Appalachian Mountains. In the following years, several additional studies have investigated the crustal structure of this region (Hughes et al. 1993; Holbrook et al. 1994; Marillier et al. 1994; Zelt and Forsyth 1994; Musacchio et al. 1997; Pratt et al. 1988, 2014).

Most of these studies are focused on either the Appalachian orogeny or the offshore Atlantic margin. On land, seismic reflection profiles reported by Cook et al. (1979, 
1981) and Pratt et al. (1988) revealed the crustal structure beneath the coastal plain in Georgia and the crustal structure of the Virginia Piedmont, respectively. Sheridan et al. (1993) deduced the crustal structure of the coastal plain in Virginia from an offshore active-source seismic reflection profile. Holbrook et al. (1994) obtained the P-wave velocity model beneath one of the profiles in Sheridan et al. (1993) with multichannel and wide-angle seismic data. Hales et al. (1968) and Lewis and Meyer (1977) obtained a P-wave velocity model from onshore to offshore by active wide-angle seismic profiles. There are only a few seismic profiles located on the coastal plain between the central Appalachian orogen and Atlantic margin. Dreiling and Mooney (2015) obtained the P- and $\mathrm{S}$-wave velocity upper crustal structure and attenuation beneath Piedmont, with the aftershocks recorded by a dense seismic array. Shen and Ritzwoller (2016) present a 3-D shear wave velocity model of crust and uppermost mantle beneath the contiguous US from the inversion of Rayleigh wave group and phase speeds, receiver functions, and Rayleigh wave ellipticity (H/V) measurements. The crustal structure beneath the piedmont and coastal plain can be extracted from the model. However, the 3D model in Shen and Ritzwoller (2016) is formed by interpolating several depth-dependent statistics onto a $0.25^{\circ} \times 0.25^{\circ}$ across the US by simple kriging. For the analysis of a relatively small region, e.g. our study area, Shen and Ritzwoller (2016) present only a rough model. Lynner and Porritt (2017) present the crustal structure across the eastern North American margin from ambient noise tomography and focus on the interpretation of the ocean-continental transitional crust and the East Coast magnetic anomaly. Given the previous seismic data, it is still unclear to what extent the Appalachian and Laurentian terranes exist beneath the coastal plain, or whether the coastal plain is its own unique crustal section. To evaluate the roles of tectonic inheritance and magmatism on rifting and rupture, and to understand the evolution of this rifted margin, it is important to understand the crustal structure and composition beneath the coastal plain.

The NSF-funded GeoPRISMS program conducted two land-based active-source seismic wide-angle reflection/refraction profiles across the eastern Piedmont and coastal plain of North Carolina and Virginia in 2015 (Fig. 1). In this paper, we describe the processing and analysis of the Line 1 seismic refraction/wideangle reflection profile. We present the $\mathrm{P}$ - and $\mathrm{S}$-wave velocity structure, Poisson's ratio, and infer the crustal composition based on a comparison with laboratory measurements of P-wave velocities and Poisson's ratio. For further analysis, we integrate our results with other seismic data to form the crustal model from Atlantic
Sea to Appalachians mountains. We also compare two examples of rifted crustal structure with our study to better understand the nature of ENAM margin. One is the Kenya Rift of the East African Rift System (EARS), which has a narrow rift mode (Buck 1991); the other is an example of wide rift mode, the South China Sea (SCS) rift (Wan et al. 2017). And the SCS rift and the ENAM rift are fully developed rifting margin (Buck 1991; Brune et al. 2016; Wan et al. 2017), while the Kenya Rift is a youthful narrow rift and appears to be an example of early-stage continental rifting (Buck 1991; Ebinger 1989). The crustal structure for both of these two rifts are also modeled by seismic wide-angle reflection/refraction data (Maguire et al. 1994; Wan et al. 2017; Zhang et al. 2013), and their modeling technique is similar to our technique, that make the comparison more reliable.

\section{Geological setting}

The morphology of the eastern North American margin was shaped over the course of two supercontinent cycles, including the formation and subsequent breakup of both Rodinia and Pangaea (Thomas 2006). Our study area is located between the Appalachian orogeny and the Atlantic Ocean, recording a complex history of repeated continental collision and rifting (Fig. 2).

The Appalachians were formed by four main orogenies: The Grenville (Mesoproterozoic), the Taconic (Ordovician), the Acadian/Neo-Acadian (Devonian-Mississippian), and the Alleghanian (Pennsylvanian-Permian) (Hatcher 2007; Massey and Moecher 2005). The Grenville orogeny occurred during the formation of the supercontinent Rodinia in the late Mesoproterozoic, forming the basement rock for most of the Appalachians (Hatcher 2007). A period of rifting occurred in the early Paleozoic, leading to the breakup of Rodinia and the opening of the Iapetus Ocean (Hartz and Torsvik 2002). Within the Iapetus Ocean, a volcanic island arc formed, later being accreted onto Laurentia (Anderson and Moecher 2009). As part of the Taconic orogeny in the Ordovician, this volcanic island arc accretion was due to the closing of the Iapetus Ocean (Anderson and Moecher 2009). The Acadian orogeny in the Appalachians occurred due to the oblique convergence of the North American craton with the Avalonian microcontinent during the Devonian (Ettensohn 1985). The Alleghanian orogeny was the final major orogenic event to take place in the Appalachians, in which thrusting occurred due to the collision between Gondwana and Laurentia at the end of the Paleozoic (Hatcher 2007).

The eastern US passive margin formed as a result of rift-to-drift tectonics associated with the breakup of Pangea during the Triassic-Jurassic (Withjack et al. 1998). The rifting associated with breakup of Pangea began 


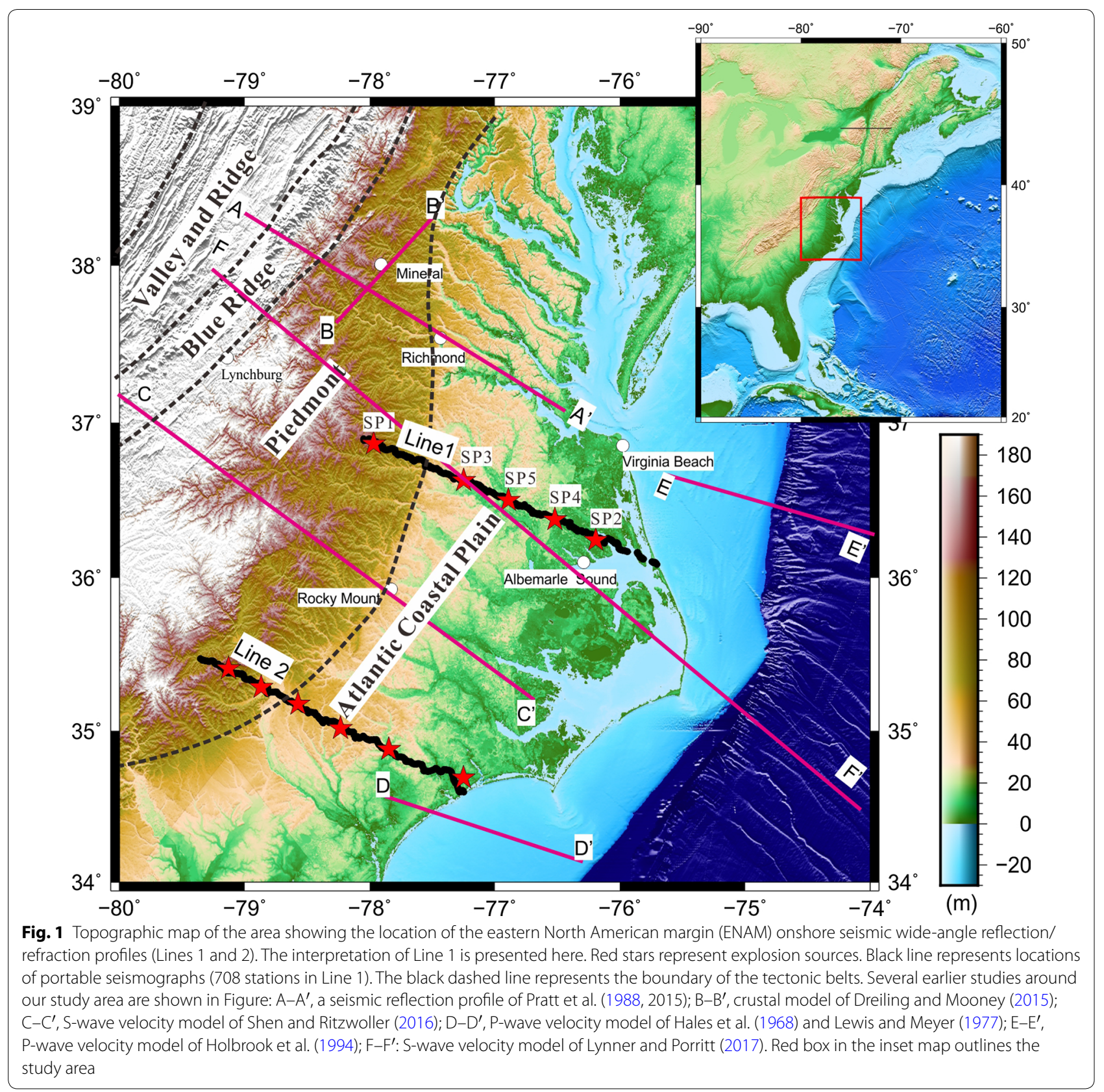

in the Middle to Late Triassic, ending with the successful separation of Africa and North America in the Early Jurassic (Withjack et al. 1998). Post-rifting magmatism, named the eastern North American (ENA) magmatic activity, occurred for a short period of time ( 600,000 years) during the Early Jurassic (Olsen et al. 1989, 1996; Withjack et al. 1998). This magmatic activity ended up forming a massive volcanoclastic wedge, which formed along the eastern US passive margin, during the rift-to-drift transition (Sheridan et al. 1993; Withjack et al. 1998). Shortly after the ENA magmatic activity, the rift-to-drift transition occurred, as the formation of seafloor spreading centers led to the formation of a passive margin along the eastern USA (Withjack et al. 1998).

A previous land seismic reflection survey done in Georgia inferred that sedimentary and metamorphic rocks were thrust landward as a result of ocean-basin closures, suggesting thin-skinned tectonics within the Blue Ridge and Piedmont (Cook et al. 1979, 1981). Seismic data gathered by USGS in Virginia (close to the seismic profile in this study) support this thin-skinned model (Pratt et al. 1988). Previous studies also interpret the eastern North 


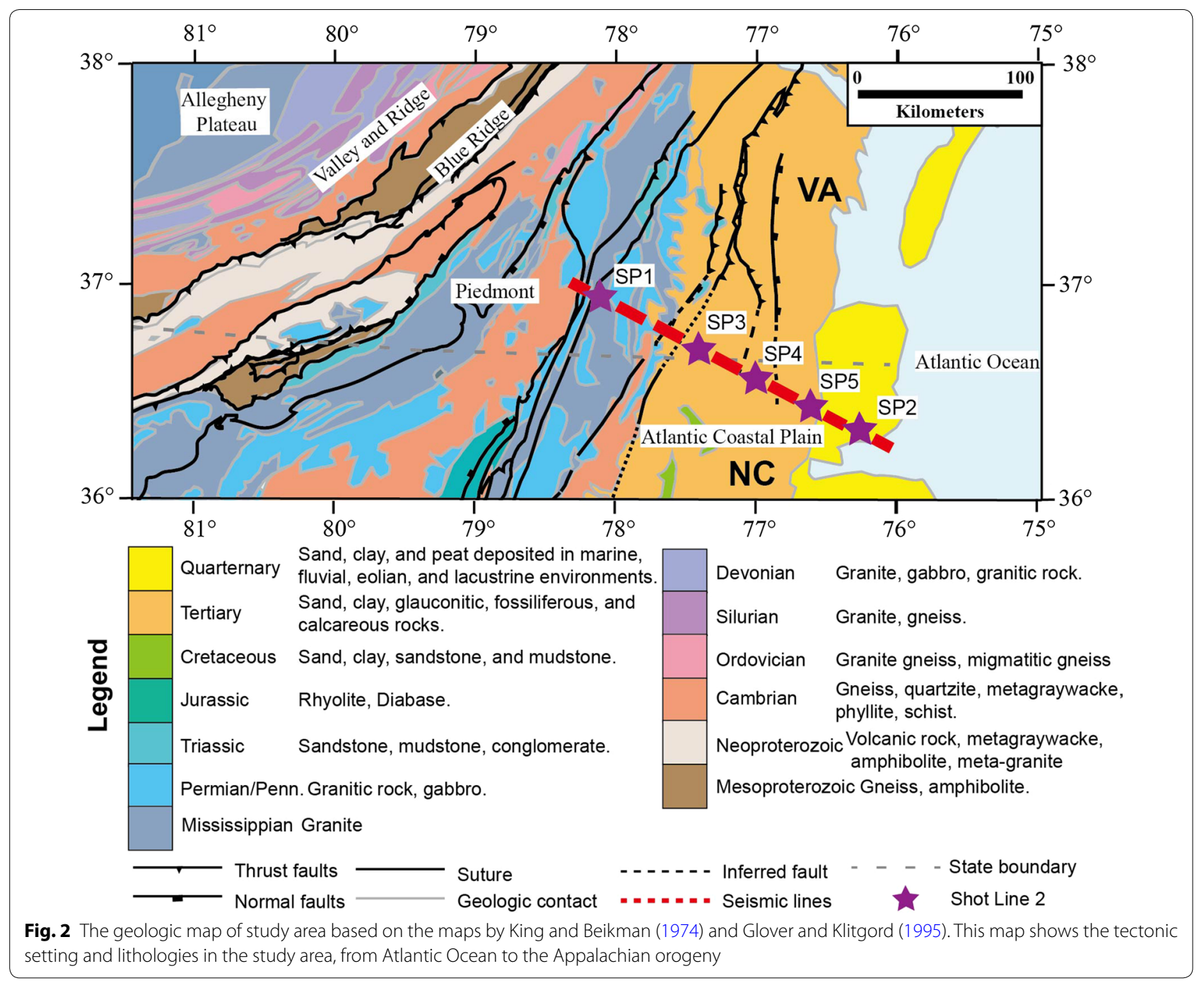

American margin as a strongly volcanic margin, which are generally indicated by the presence of dipping reflectors within the transitional crust and crustal underplating of igneous materials (Klitgord et al. 1988; Tréhu et al. 1989; Holbrook et al. 1994; White and McKenzie 1989). There is also a stark transition in crustal thickness across the margin, and the Moho boundary is sharply uplifted in the transition between continent and ocean crust (Holbrook et al. 1994; Lynner and Porritt 2017).

\section{Data acquisition and seismic phase analysis}

This active-source seismic refraction/wide-angle reflection profile is $220 \mathrm{~km}$ long and consists of 5 borehole explosions. Each borehole was filled with $182 \mathrm{~kg}$ of bulk emulsion (Dyno-Nobel Titan 1000SD) with electronic (Dyno-Nobel Geoshot) detonators. The seismic data were recorded by 708 vertical component seismographs, equipped with $4.5 \mathrm{~Hz}$ geophones, at a sample rate of
$4 \mathrm{~ms}$. The shot spacing between the two shots in the west is about $70 \mathrm{~km}$, whereas the shot spacing for the three eastern shots is $30 \mathrm{~km}$ (Fig. 1). The seismograph spacing is about $320 \mathrm{~m}$. Acquisition of the active-source seismic data took place in June 2015 by volunteers from various universities and USGS.

The recorded P-wave seismic data obtained by the wide-angle seismic survey have a high signal-to-noise ratio that does not require filtering (Fig. 3a). We identified direct basement arrivals as $\mathrm{Pg}$, refracted phase from uppermost mantle as Pn, and wide-angle reflected phases as $\mathrm{PxP}$, where $\mathrm{x}$ is the crustal boundary number, 1 being the shallowest crustal boundary and $\mathrm{m}$ being the Moho. Based on the reciprocal traveltimes, six principal seismic phases (Pg, P1P, P2P, P3P, P4P, and PmP) have been identified (Fig. 3). The energy of Pn is strong but only visible in the seismic record of SP2 (Fig. 3c), and we picked it without reciprocal traveltimes. After the application 

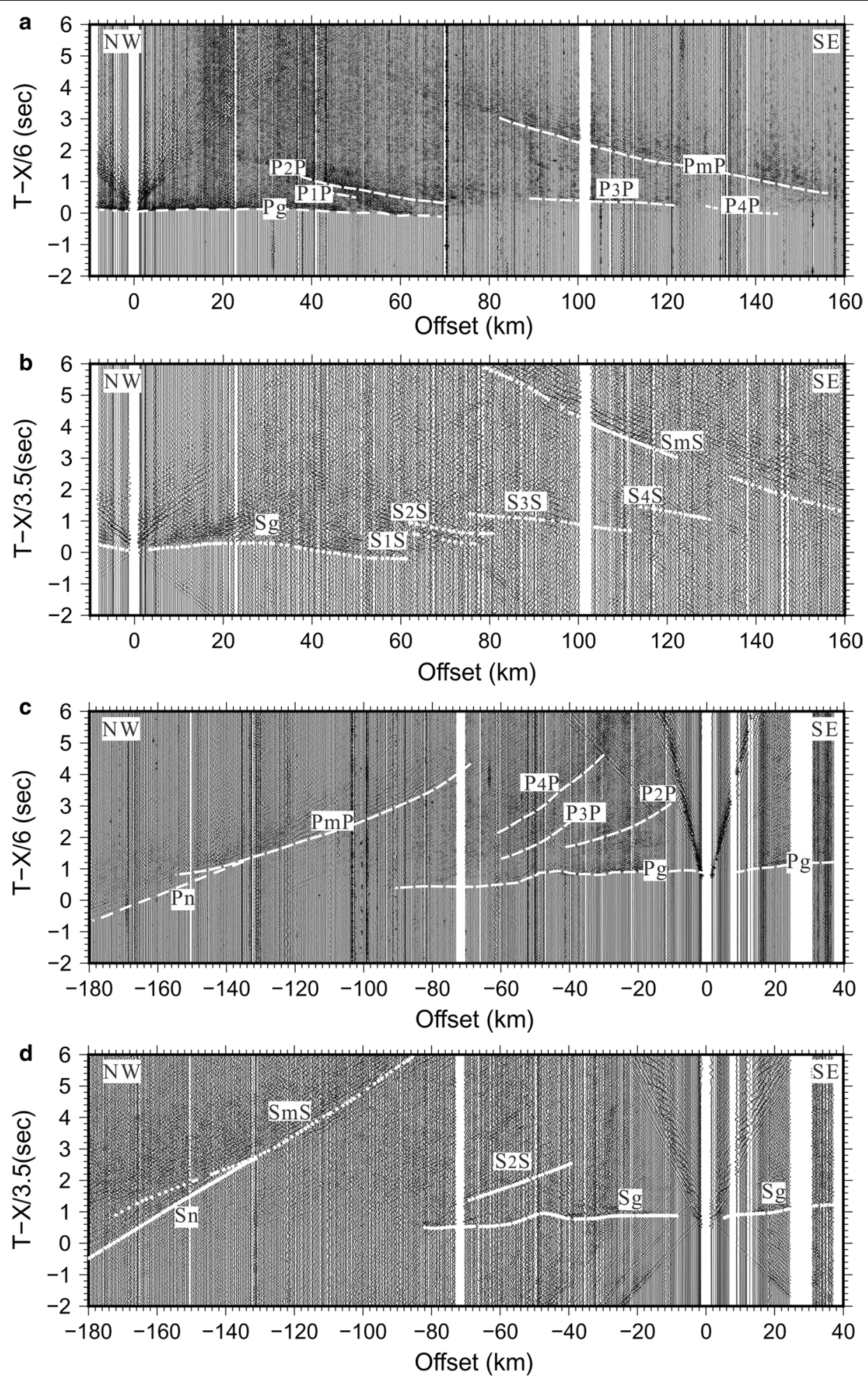

Fig. 3 Record section generated by the westernmost shot SP1 and easternmost shot SP2 are plotted at a reduction velocity $6 \mathrm{~km} / \mathrm{s}$, and the amplitudes are normalized for each trace. The white dashed lines indicate the picked travel times. These is no filter for the P-wave record section, while an Ormsby band-pass filter of $2-12 \mathrm{~Hz}$ is used for the S-wave record section to enhance the signal-to-noise ratio. a The P-wave record section of SP1. Six principal seismic phases (Pg, P1P, P2P, P3P, P4P, and PmP) have been identified based on the reciprocal traveltimes. $\mathbf{b}$ The S-wave record section of SP1. Six principal seismic phases (Sg, S1S, S2S, S3S, S4S, and SmS) have been identified. c The P-wave record section of SP2. Six principal seismic phases (Pg, P1P, P3P, P4P, PmP, and Pn) have been identified. The uppermost mantle refraction Pn is only visible in the record section of SP2. d The S-wave record section of SP2. After a filter, only four principal seismic phases (Sg, S2S, SmS, and Sn) have been identified 
of an Ormsby band-pass filter of $2-12 \mathrm{~Hz}$, the S-wave refraction and reflections are visible in these vertical component records (Fig. 3b, d). With the relationship between P-wave and S-wave (Christensen 1996; Christensen and Mooney 1995; Musacchio et al. 1997), we can make sure the $S$-wave reflections $S \times S$ and corresponding $\mathrm{P}$-wave reflections $\mathrm{P} \times \mathrm{P}$ are generated by the same crustal boundary.

\section{Amplitude synthetic}

As is typical for such seismic profiles, the wide-angle reflected arrivals are significantly stronger than refracted arrivals. The velocity of each crustal layer could be evaluated by the amplitude of seismic reflection phase $\mathrm{P} \times \mathrm{P}$ (Braile and Smith 1975; Giese et al. 1976; Jia et al. 2014; Musacchio et al. 1997; Pakiser and Mooney 1989; Zelt and Smith 1992; Zhang et al. 2009, 2013). So, the onedimensional (1D) synthetic seismogram (Fuchs and Müller 1971; Sandmeier and Wenzel 1986) is used to model the seismic travel times and amplitudes of each of the record sections to generate an initial model before we do the $2 \mathrm{D}$ modeling of the data. Because the energy of $\mathrm{P} 1 \mathrm{P}$ and P2P is strong and complex, showing an unusual feature of crustal reflections, the amplitude analysis of the seismic record including these reflections is presented here.

Two different 1D velocity models (Fig. 4) are used to calculate the synthetic waveforms of SP1 (Fig. 3a). One model has a low-velocity zone (LVZ, $5.7 \mathrm{~km} / \mathrm{s}$ ) at depths of 9-11 km, and another doesn't have the LVZ. Both the synthetic traveltimes (Fig. 4a) match well with the record section (Fig. 3), but the amplitudes of the two models are different. The strongest energy of the reflections is associated with the critical angle, which in turn is dependent on the crustal velocity structure (Brail and Smith 1975). The presence of the LVZ makes the strongest energy of P2P appear closer to the source, leading to a group of strong and continuous reflections which are in agreement with the observed seismic waves labeled as $\mathrm{P} 1 \mathrm{P}$ and $\mathrm{P} 2 \mathrm{P}$ in the record

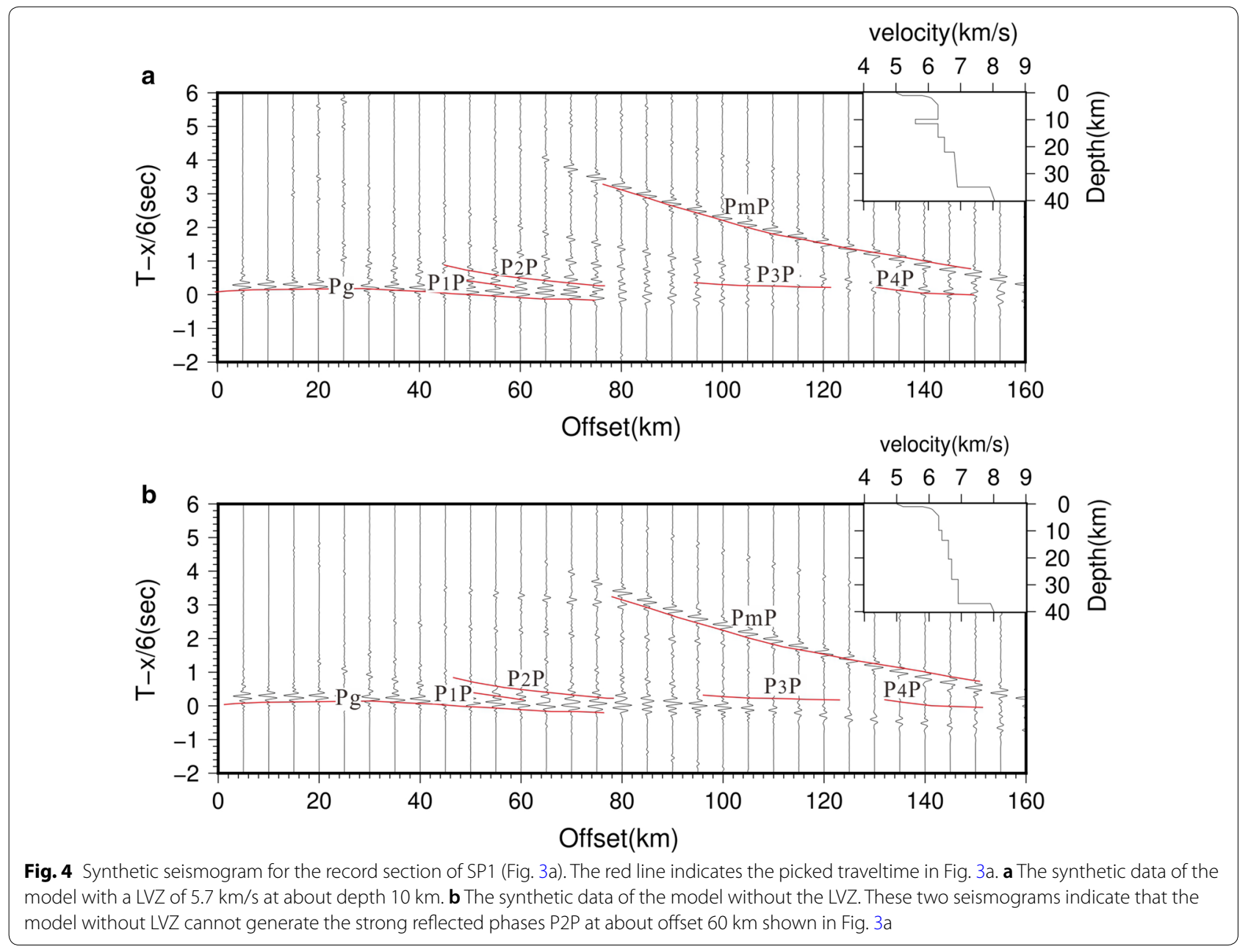


section (Fig. 3). The LVZ also affects the amplitudes of P3P and P4P. In summary, without the LVZ, the amplitudes, distances, and traveltimes of the reflections are inconsistent with the observed data (Fig. 4b).

\section{Normal moveout correction for the LVZ}

To further evaluate the P1P and P2P, a simple hyperbolic normal moveout correction was applied to each seismic trace (Luetgert et al. 1987). The recorded seismogram time was converted to two-way travel time (TWTT) using the equation $T_{\text {nmo }}=\sqrt{T^{2}-x^{2} / v^{2}}$, where $v$ is $6.1 \mathrm{~km} / \mathrm{s}$, the average velocity of upper crust, $x$ is the source-receiver distance, and $\mathrm{T}$ is time. The depth is then estimated by $D=v \times T_{\mathrm{nmo}} / 2$. The result (Fig. 5) shows that the estimated depth of the strongest reflections, P2P, is about $12-13 \mathrm{~km}$, which spatially corresponds to the bottom of the LVZ determined by synthetic seismogram modeling.

\section{The seismic phases around Pg}

In addition to the reflections $\mathrm{P} 1 \mathrm{P}$ and $\mathrm{P} 2 \mathrm{P}$, there are also other complex reflections near the P-wave refraction Pg (Fig. 6). There are no reciprocal traveltimes for these reflections, and their origins are more uncertain. We analyze them after the $2 \mathrm{D}$ modeling. The Pg is also complex (Fig. 6b): The traveltime step of Pg indicates that there possibly is a basin or thick sediments, and the disappearance of Pg in the record section of SP3 indicates there is the LVZ in the subsurface (Park et al. 2010). All the characters indicate that the upper crustal structure is complex beneath this profile, consistent with the complex tectonic and lithology in the study area (Fig. 2).

\section{Velocity modeling}

\section{$\mathrm{P}$ - and S- wave velocity modeling}

Based on an analysis of the seismic phases, we manually picked the reflection and refraction traveltimes. The uncertainties of the picked traveltimes range from 50 to $100 \mathrm{~ms}$ based on the quality of the records and the empirical parameterization (Zelt and Forsyth 1994; Liu et al. 2006; Wan et al. 2017).

Rayinvr program (Zelt and Smith 1992) is an efficient ray tracing method for velocity modeling of wide-angle seismic data (Bezada et al. 2010; Delescluse et al. 2015; Wan et al. 2017; Zelt and Smith 1992; Zelt and Forsyth 1994). As previously mentioned, the upper crustal structure along the profile is complex, generating significant complex Pg phase. It is difficult to model the complex seismic structure with a ray tracing method (Hole and Zelt 1995; Zelt and Barton 1998). So we use a regularized first-arrival time inversion algorithm (Zelt and Barton 1998) to obtain the tomographic model of Pg, resample the model, and obtain the whole crust model with other seismic phases (P1P, P2P, P3P, P4P, PmP and Pn) by employing Rayinvr program (Bezada et al. 2010).

After the inversion of all the seven principal seismic phases (Pg, P1P, P2P, P3P, P4P, PmP, and Pn), we obtained two crustal velocity models beneath the seismic profile line (Fig. 7a, b). We firstly obtained the upper crustal structure $(0-7 \mathrm{~km}$ of Fig. $7 \mathrm{a})$ by inverting the Pg traveltimes and then resampled the model to yield an initial model for the inversion of other seismic reflection phases (Fig. 7b). During the inversion of the deeper seismic reflection phases, the upper crustal velocity structure is fixed. To obtain the optimal model, we replaced the upper crust of Fig. 7b with the original upper crustal structure obtained by Pg inversion to yield Fig. 7a. This step was taken because the upper crustal structure in

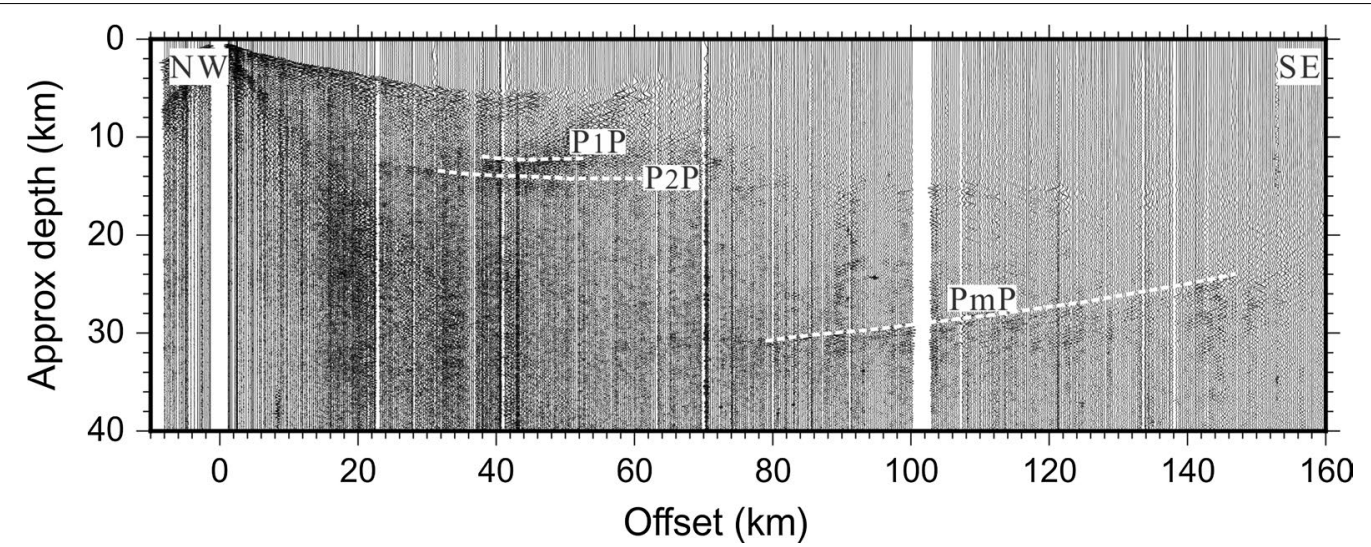

Fig. 5 Normal moveout (NMO) correction of the SP1 seismic record. The normal moveout velocity is $6.1 \mathrm{~km} / \mathrm{s}$. This NMO record section highlights the P1P and P2P wide-angle reflections. The white dashed lines indicate the picked travel times 

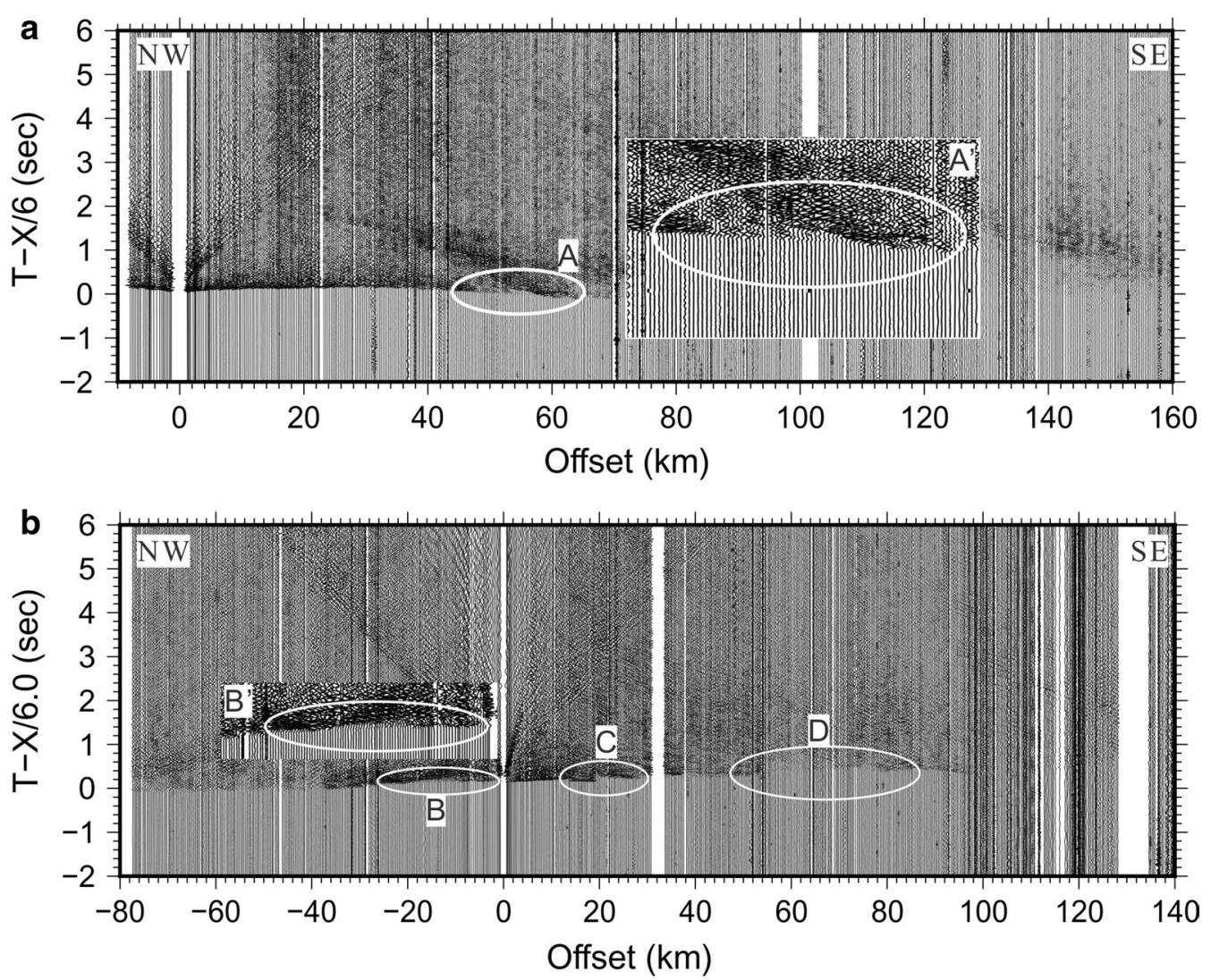

Fig. 6 a The record section of SP1. Region $A^{\prime}$ is the expansion of region A, showing that there is a strong reflection after the Pg phase. $\mathbf{b}$ The record section of SP3. Region $\mathrm{B}^{\prime}$ is the expansion of region $\mathrm{B}$, indicating there is a reflection after $\mathrm{Pg}$. It is close to $\mathrm{Pg}$, so it is possibly generated by the very shallow structure. Region C shows a step of $\mathrm{Pg}$, and region D shows that there is a shadow zone between 60 and $80 \mathrm{~km}$, indicating a low-velocity zone (LVZ) in upper crust (Park et al. 2010). Note that this LVZ is not the LVZ above (Figs. 3a, 5); rather this LVZ is much shallower and smaller

Fig. $7 \mathrm{a}$ is more accurate than in Fig. 7b. Considering that both the characters of seismic record section and the surface geology indicate a complex upper crustal structure, a more accurate upper crust is helpful for the geological interpretation presented below.

The approximate $\mathrm{S}$-wave arrival times may be estimated by multiplying the P-wave arrival times by 1.732 $(\sqrt{ } 3)$. However, laboratory measurements of the $V p / V s$ ratio for a variety of rock compositions suggest that the observed S-wave arrival times can range from 1.45 to 1.9 times the P-wave arrival time (Christensen 1996; Christensen and Mooney 1995; Musacchio et al. 1997). Thus, we calculated the approximate S-wave traveltimes by multiplying the P-wave traveltimes by 1.732 , and use them to guide the identification of actual traveltimes of the S-wave phases (Musacchio et al. 1997). We then obtained the S-wave crustal structure using the same technique as used in the P-wave velocity inversion (Fig. 8).

There are alternate low- and high-velocity zones at depths of $0-6 \mathrm{~km}$ in the upper crust (Figs. 7, 8). This may correspond to the geology of the study area, which is complex (Fig. 2). We note that our data have the ability to identify some small geological bodies because of the dense seismographs (spacing of $320 \mathrm{~m}$ ). We next analyze the reliability of the $\mathrm{P}$ - and $\mathrm{S}$-wave velocity structure by RMS, $\chi^{2}$, checkerboard test and model uncertainty.

\section{Resolution and Uncertainties of the crustal velocity model}

Before discussing geological interpretations, it is important to give a clear notion of the robustness and reliability of the $\mathrm{P}$ - and S-wave crustal velocity models. The RMS traveltime misfits and $\chi^{2}$ values listed in Table 1, and the ray density evident in the ray diagram (Fig. 9) gives a measure of the reliability of the model. Because different methods are used to invert the refraction and reflection phases, we applied the checkerboard test (Zelt and Barton 1998) to test the resolution of upper crust, and calculated the uncertainty (Zelt 1999) of other layers. 

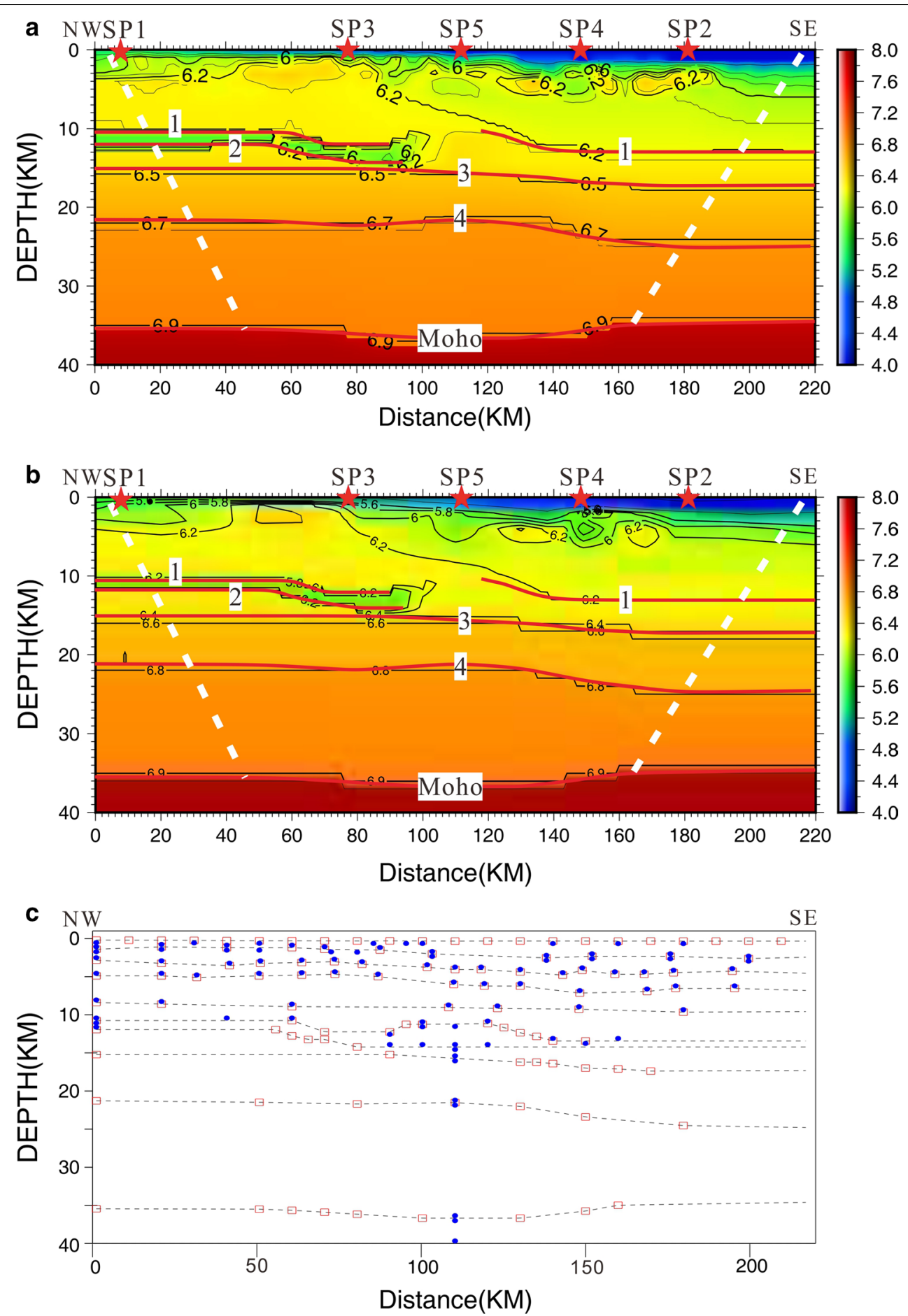

Fig. 7 P-wave velocity structure along the Line 1 seismic profile and the model structure of Rayinvr program. The red line indicates the reflection boundaries used in the inversion. The red stars indicate the shotpoints (SP). There is no seismic coverage beyond the white dashed lines. The wide-angle reflections P1P, P2P, P3P, P4P, and PmP are generated from boundaries 1, 2, 3, 4, and Moho, respectively. a The velocity structure obtained by the regularized inversion algorithm of the first-arrival traveltimes and Rayinvr program. $\mathbf{b}$ The crustal velocity structure obtained by using Rayinvr. c The nodes we used to model the seismic velocity structure of Fig. $7 \mathrm{~b}$. The red boxes indicate the nodes used to model the boundaries in the crust, and the blue dots used to indicate the seismic velocity nodes above and beneath the boundaries. The nodes between 0 and $7 \mathrm{~km}$ are used to resample the upper crustal model obtained by Pg inversion ( $0-8 \mathrm{~km}$ of Fig. $7 \mathrm{a}$ ), and they are fixed in the employment of Rayinvr program. The other nodes are adjusted to obtain Fig. $7 \mathrm{~b}$ with the seismic phases (P1P, P2P, P3P, P4P, PmP and Pn) 


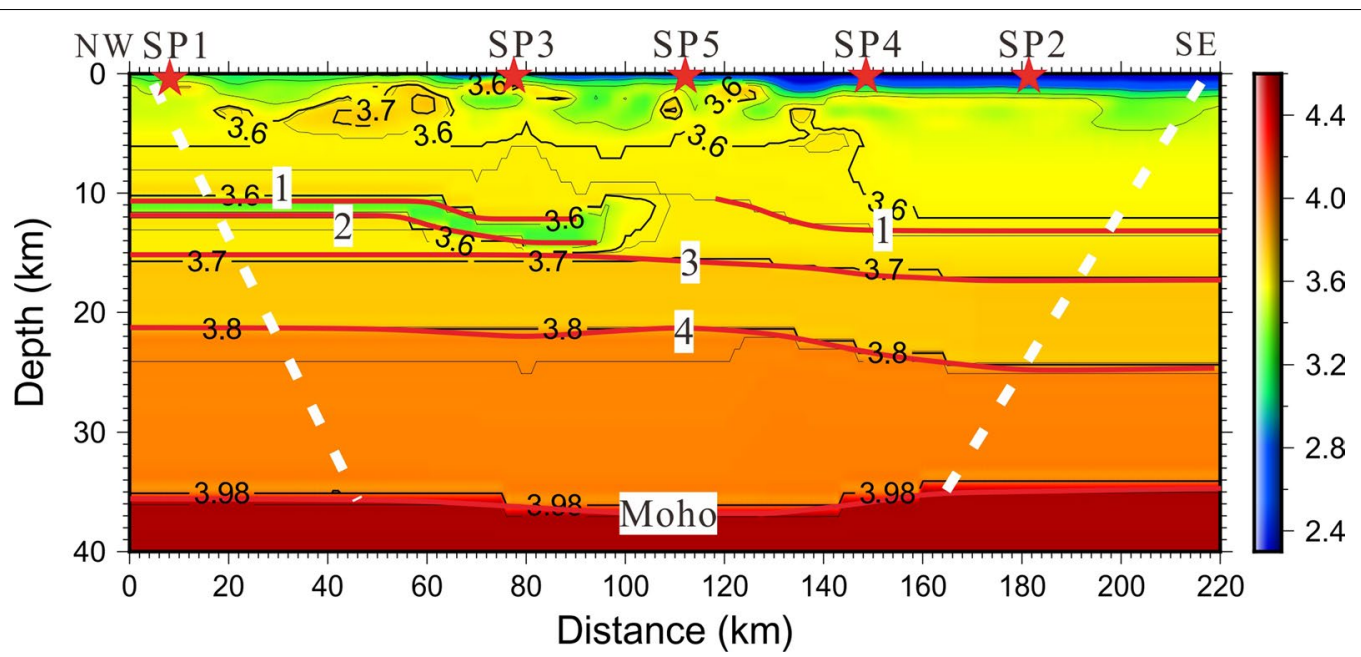

Fig. 8 S-wave velocity structure along the Line 1 seismic profile. The red line indicates the reflection boundaries used in the inversion. The red stars indicate the shotpoints (SP). As is evident in the seismic ray diagrams (Fig. 9), there is no seismic coverage beyond the white dash lines. The wide-angle reflections S1S, S2S, S3S, S4S, and PmP are generated from boundaries 1, 2, 3, 4, and Moho, respectively

\section{Checkerboard test of the upper crust}

A checkerboard test consisting of a $5 \times 2 \mathrm{~km}$ grid is used to evaluate the model resolution within the upper crust. For this purpose, a $5 \%$ velocity perturbation is added on the final model to create the input checkerboard model. The inverted data are the synthetic data of the checkerboard assuming an uncertainty of $50 \mathrm{~ms}$ for P-wave and $80 \mathrm{~ms}$ for $\mathrm{S}$-wave. The inversion parameters and processing are in accordance with the values used in the tomographic inversion of the observed

Table 1 RMS misfit and $\chi^{2}$ values for individual seismic phases

\begin{tabular}{lcccl}
\hline Seismic phase & $\begin{array}{l}\text { No. of picked } \\
\text { travel times }\end{array}$ & RMS (ms) & $\chi^{\mathbf{2}}$ & $\begin{array}{l}\text { Uncertainty } \\
\text { of the picks } \\
(\mathbf{m s})\end{array}$ \\
\hline Pg & 1647 & 49 & 1.02 & 50 \\
P1P & 508 & 57 & 0.60 & $80-100$ \\
P2P & 121 & 57 & 0.74 & $80-100$ \\
P3P & 186 & 58 & 1.12 & $80-100$ \\
P4P & 255 & 58 & 0.73 & $80-100$ \\
PmP & 482 & 63 & 0.99 & $80-100$ \\
Pn & 85 & 63 & 0.72 & $80-100$ \\
Sg & 575 & 115 & 1.33 & 100 \\
S1S & 190 & 115 & 1.34 & $100-150$ \\
S2S & 46 & 66 & 0.45 & $100-150$ \\
S3S & 58 & 116 & 1.37 & $100-150$ \\
S4S & 73 & 133 & 1.78 & $100-150$ \\
SmS & 275 & 116 & 1.08 & 100 \\
Sn & 97 & 77 & 0.60 & 100 \\
\hline
\end{tabular}

data. Both the P-and S-wave models are well recovered (Fig. 10). The recovered depth of the P-wave model is about $3 \mathrm{~km}$ in the western portion of the profile and about $5 \mathrm{~km}$ in the eastern portion. The recovered depth for the $\mathrm{S}$-wave checkerboard test is about $4 \mathrm{~km}$ along the seismic line, showing a more homogeneous result than the P-wave checkerboard test, consistent with the ray coverage of the P- and S-wave model (Fig. 9).

A significant feature of the crustal velocity model (Fig. 7) is the alternate low- and high-velocity bodies obtained by inverting the Pg traveltimes in the upper crust at $0-5 \mathrm{~km}$ depths. According to the result of the checkerboard test, the low velocity at a distance of $0-20 \mathrm{~km}$ and the high velocity at the distance of $40-60 \mathrm{~km}$ are reliable because these two velocity bodies are larger than the recovered checkerboard cell size. As the velocity contrast between these two velocity zones and the velocity around is large, the shallow reflections A, B in Fig. 6 are possibly generated by the boundary of these velocity bodies. Some low-velocity features at a distance of $100-200 \mathrm{~km}$ are equal or even smaller than the checkerboard size, and most of them are located at the depth of 3-6 km. The sparse ray coverage at this depth also decreases the reliability of these velocity anomalies. However, shadow zones of Pg (Fig. 7) indicate that there should be a low-velocity zone in these areas. Considering the good match between the calculated and picked traveltimes $\left(\chi^{2}=1.02\right.$ for Pg and 1.33 for Sg in Table 1), we adopt this complex upper crustal model rather than assuming that it is a result of the over-fitting of the traveltimes. 

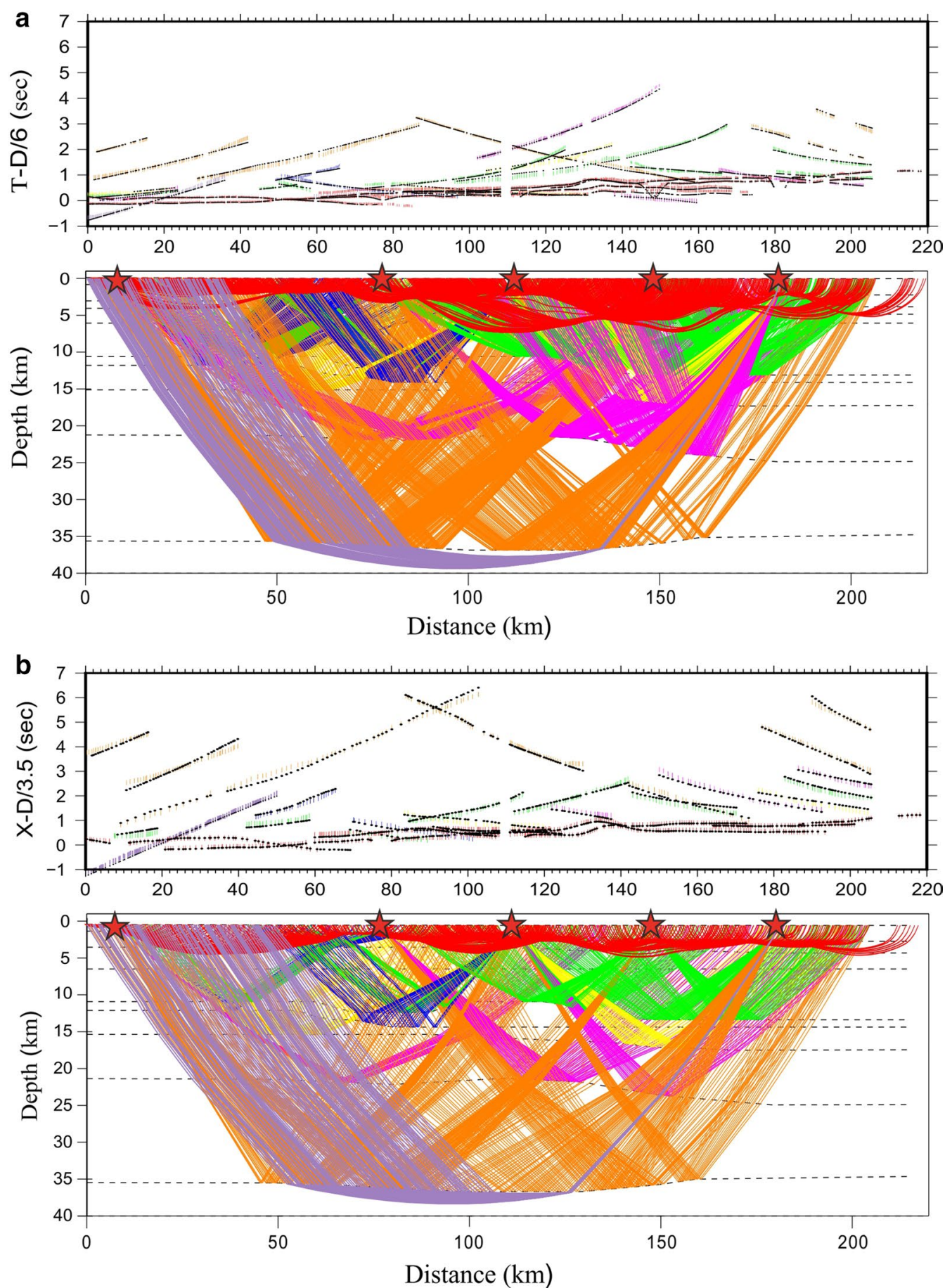

Fig. 9 a The P-wave traveltime fit and seismic ray diagram. $\mathbf{b}$ The S-wave traveltime fit and seismic ray diagram. The rays emanate from each of the five shot points and are color coded by the crustal boundary from which they either refract or reflect. The density of ray coverage gives a qualitative indication of which portions of the model are well constrained. The short color segment is the observed times of the rays which have the same color in the seismic ray diagram. The length of segments indicates the estimated picking error. The black nodes are the calculated times

\section{Uncertainty of the crustal boundary}

In this study, we compare observed seismic amplitudes with synthetic seismograms to estimate the P-wave velocity contrast at each crustal boundary. Forward modeling indicates the uncertainty of the velocity in each crustal layer to be $\pm 0.1 \mathrm{~km} / \mathrm{s}$. This velocity uncertainty 

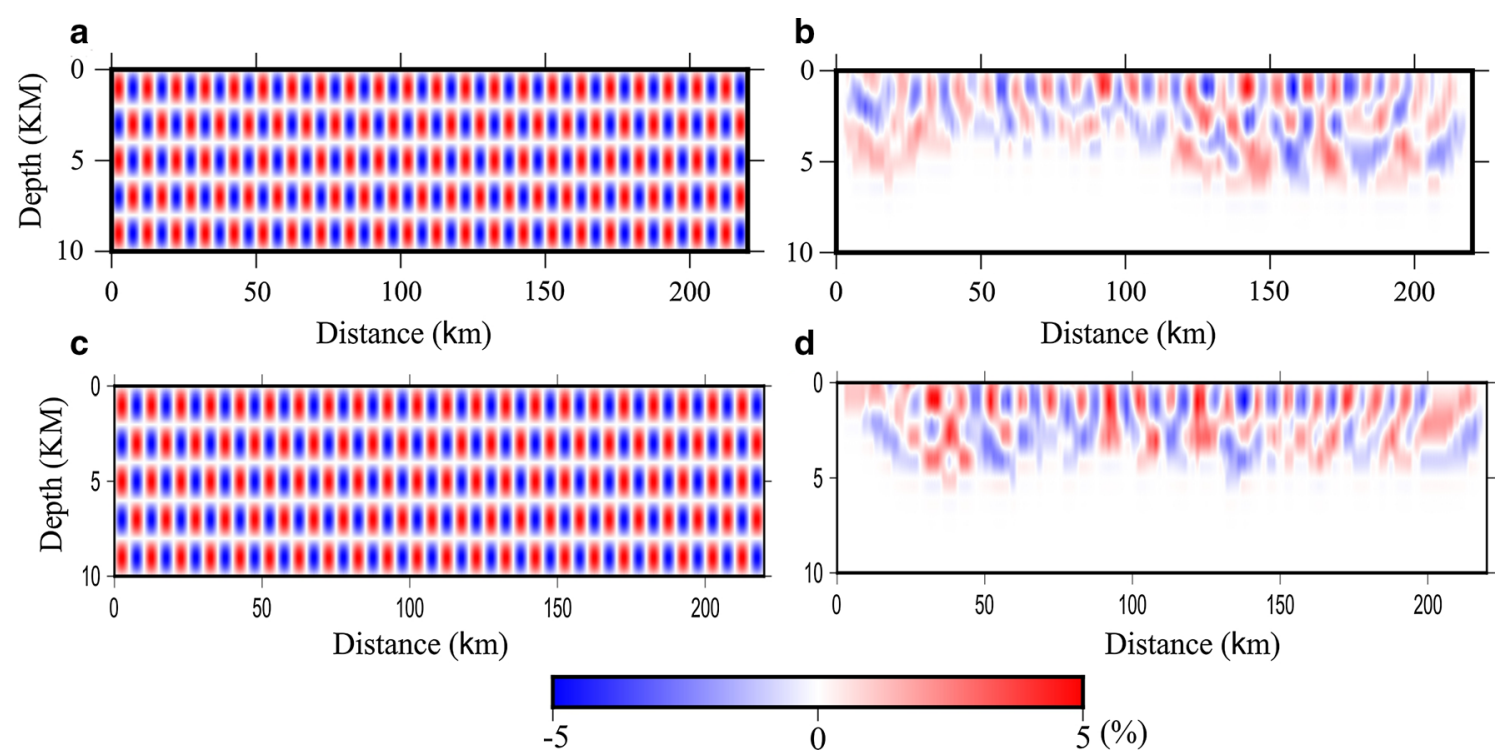

Fig. 10 Results of checkerboard resolution tests for the upper crust of P-wave velocity model. $\mathbf{a}$, $\mathbf{b}$ Respectively the $5 \times 2 \mathrm{~km}$ checkerboard and the recovered result for the P-wave velocity model. $\mathbf{c}$, $\mathbf{d}$ Respectively the $5 \times 2 \mathrm{~km}$ checkerboard and the recovered result for the S-wave velocity model

causes a $\pm 0.7 \mathrm{~km}$ variation for the depth of each boundary except the bottom boundary of the LVZ. Because the LVZ is only $\sim 2 \mathrm{~km}$ thick, $\mathrm{a} \pm 0.1 \mathrm{~km} / \mathrm{s}$ variation of the velocity is not large enough to change the depth of the boundary significantly. We also used the method suggested by Zelt and Barton (1998) to test the uncertainty of the model. In the process of data modeling, we assumed that the crustal structure, both in terms of the lateral distribution of the seismic velocity and the geometry of the boundary, should be as simple as possible. So we only use one velocity node for each layer, and as few boundary nodes as possible (Fig. 7c). The uncertainty of each node is $1.0-1.5 \mathrm{~km}$, but if the boundary is smooth, the uncertainty is less than $0.7 \mathrm{~km}$. The locations of the boundaries of the $\mathrm{S}$-wave velocity model are assumed to be the same as the boundaries of the P-wave velocity; the $\pm 0.7 \mathrm{~km}$ variation in depth causes a $\pm 0.05 \mathrm{~km} / \mathrm{s}$ variation for S-wave velocity.

\section{Poisson's ratio}

Poisson's ratio along the profile was calculated using the final P- and S-wave seismic velocity models (Fig. 7) and mainly ranges from 0.24 to 0.26 for the crystalline crust (Fig. 11). These values are consistent with the previously reported low crustal Poisson's ratio $(<0.27)$ of the Paleozoic Appalachian orogenic belt (Zandt and Ammon 1995). Poisson's ratio of the sedimentary cover ranges from 0.20 to 0.27 . Considering that the recovered checkerboard test of the P- and S-wave structure has a dimension of $5 \times 2 \mathrm{~km}$ (Fig. 10), the dimensions of regions with reliable Poisson's ratio should be about twice larger. Poisson's ratio within the sedimentary cover should range from 0.20 to 0.23 . Beneath the sedimentary cover, the distribution of Poisson's ratio is found to be relatively homogeneous. Poisson's ratio of the upper crust in the western portion of the seismic profile ranges from 0.25 to 0.26 . If we exclude the LVZ, this is slightly higher than the Poisson's ratio of the upper crust in the eastern region, which ranges from 0.24 to 0.25 . In the middle and lower crust, Poisson's ratio is 0.26 and 0.25 , respectively. Poisson's ratio below the Moho is about 0.27 .

\section{Gravity modeling}

Gravity modeling serves as an additional test on the validity of the Line 1 crustal velocity model and also gives an estimate of the crustal density structure. The P-wave model is parameterized as a series of polygons (Fig. 11), and the P-wave velocity within each polygon is converted to an average density value (Brocher 2005) for gravity calculation (Cady 1980; Talwani et al. 1959). The gravity data are extracted from the database of nearly one million Bouguer gravity anomaly values on the USGS Web site (https://mrdata.usgs.gov/gravity/bouguer). The Bouguer anomaly is computed using a reduction density of $2.67 \mathrm{~kg} / \mathrm{m}^{3}$. The crustal model was extended $80 \mathrm{~km}$ in both directions to avoid problems caused by model edge effect. Because the seismic wide-angle reflection data are much more sensitive to the crustal boundaries than the gravity, the crustal boundaries determined by the seismic data are fixed during the gravity modeling. 

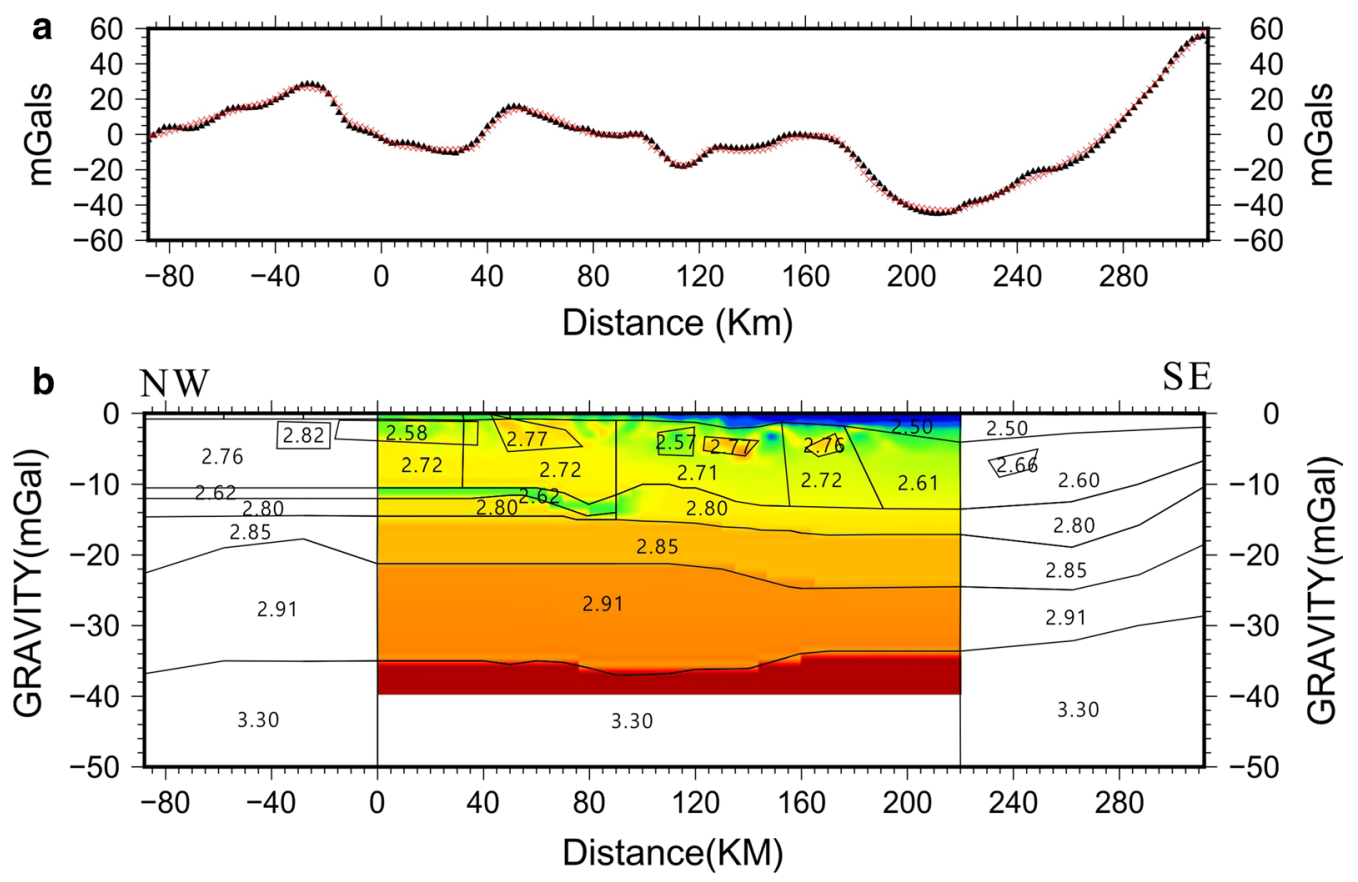

Fig. 11 Poisson's ratio along the Line 1 seismic profile. The red line indicates the reflection boundaries used in the inversion. The red stars indicate the shotpoints (SP). The white dash lines indicate the limits of the seismic ray coverage for the inversion of P-wave and S-wave velocity model. Poisson's ratio in the crystalline crust varies predominately from 0.24 to 0.26

The gravity model (Fig. 11) provides an excellent fit to the Bouguer gravity. There is a block in the upper crust with an estimated thickness of $10 \mathrm{~km}$ at a model distance of 170 to $220 \mathrm{~km}$ that corresponds to the -40 mGal Bouguer gravity anomaly. This block constitutes a significant difference between the density model and velocity model. We note that the block is located at the end of the profile where there are insufficient rays to obtain the accurate P-wave velocity. Watkins et al. (1985) modeled the -40 mGal Bouguer gravity anomaly with a 10-km-thick granite pluton (Lawrence and Hoffman 1993). We also model this anomaly with the density structure of the $10-\mathrm{km}$-thick upper crust using a block with density $2.61 \mathrm{~g} / \mathrm{cm}^{3}$, close to the density of granite $\left(2.64 \mathrm{~g} / \mathrm{cm}^{3}\right)$ measured by Christensen (1996). This is consistent with the velocity of this region (Figs. 7a, 12). In the middle and lower crust, the density is as homogenous as the P-wave velocity.

Although the geometric characteristics of the gravity model differ slightly from the velocity model at the east end of the seismic line, the overall crustal geometry inferred from the gravity and seismic models is highly consistent. The geological interpretation of this seismic velocity/density structure is discussed below.

\section{Discussion}

We compare the average seismic velocity structure of our model with previous seismic studies of the crustal P-wave and $\mathrm{S}$-wave structure near to our study area (Fig. 1). The comparison (Fig. 12) shows that the average P- and $\mathrm{S}$-wave of each crustal layer in this region are similar in all studies, but the thickness of each layer is slightly different. Our study distinguishes the crustal structure with higher resolution (for example, the low-velocity zone) because of the relatively close receiver spacing $(320 \mathrm{~m})$, and defines both the P- and S-wave velocity structure.

\section{$\mathrm{P}$ and S-wave velocity structure}

The velocity isoline of $5.7 \mathrm{~km} / \mathrm{s}$ is a commonly adopted choice for the boundary between sediment and bedrock (Christensen and Mooney 1995). There is little or no sediment on the western end of the profile (from distance $0-100 \mathrm{~km}$ ), and sediment thickness on the eastern end ranges from 2 to $4 \mathrm{~km}$ (Fig. 7a). Generally, P-wave seismic velocities in the crust range from 5.7 to $6.2 \mathrm{~km} / \mathrm{s}, 6.5$ to $6.7 \mathrm{~km} / \mathrm{s}$, and 6.8 to $6.9 \mathrm{~km} / \mathrm{s}$. These velocity ranges define the upper crust (above interface 3), middle crust (between interface 3 and 4) and lower crust (interface 4 and Moho), respectively (Fig. 7a). In the western segment 


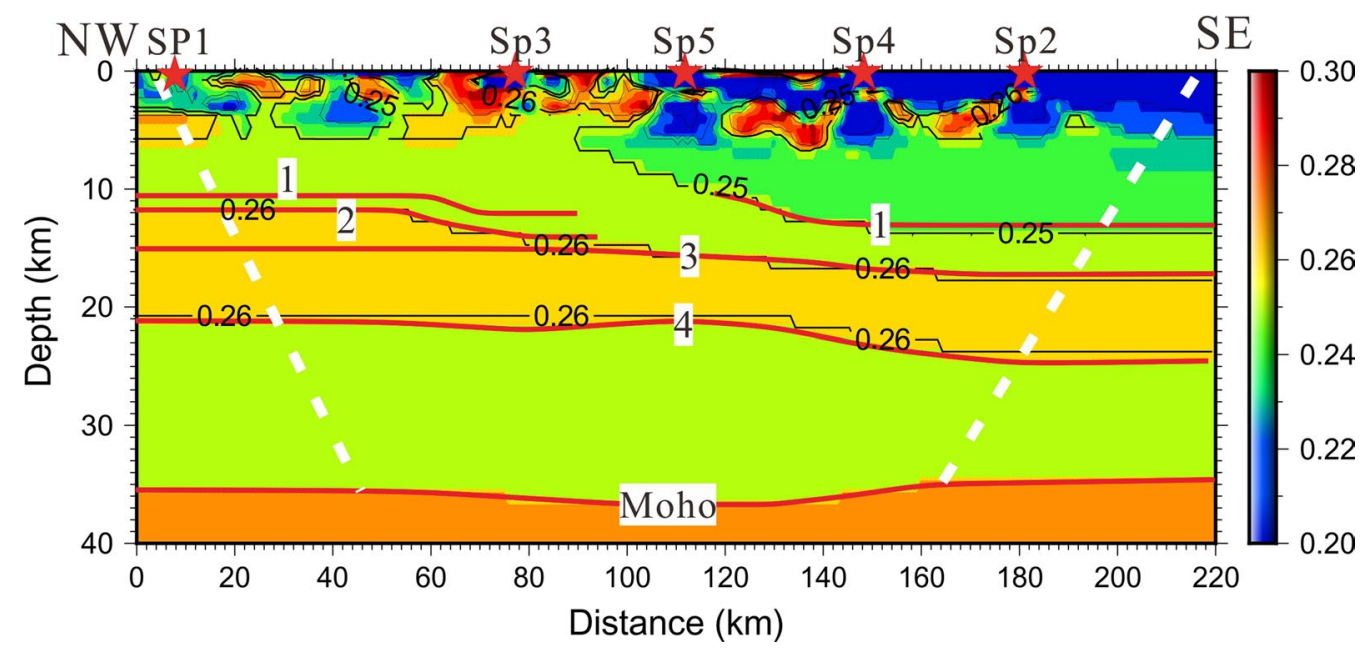

Fig. 12 a Black triangles indicate the observed Bouguer gravity anomalies and the red crosses indicate the calculated Bouguer gravity anomalies. $\mathbf{b}$ Density model used to calculate the Bouguer gravity anomalies. The density model is based on the P-wave seismic velocity structure in Fig. 8a. The numbers indicate the density $\left(\mathrm{g} / \mathrm{cm}^{3}\right)$ of the polygons

of the profile, the thickness of the crystalline crust is 35 to $37 \mathrm{~km}$, while thickness of the crystalline crust (i.e., crust minus sediments) to the east is 30 to $32 \mathrm{~km}$.

Within the upper crust, there is a 2-km-thick LVZ at a depth of 10 to $12 \mathrm{~km}$ near SP1 that extends from a model distance of $0 \mathrm{~km}$ (western end of the seismic profile) to a distance of $100 \mathrm{~km}$ (Fig. 7a). The average P-wave velocity within the LVZ is estimated to be $5.7 \mathrm{~km} / \mathrm{s}$, and the average $\mathrm{S}$-wave velocity is $3.35 \mathrm{~km} / \mathrm{s}$ based on synthetic seismogram modeling. Although large-scale lateral seismic velocity variations are not apparent, it is evident that the P-wave velocity $(6.2-6.3 \mathrm{~km} / \mathrm{s})$ at the western end of the profile is somewhat higher than in the eastern end $(6.0-6.2 \mathrm{~km} / \mathrm{s})$. In the middle crust, both P-wave and S-wave seismic velocities are uniform, $6.6 \mathrm{~km} / \mathrm{s}$ and $3.74 \mathrm{~km} / \mathrm{s}$, respectively (Fig. 7a). In the lower crust, the Pand S-wave velocities are uniform (average $6.8 \mathrm{~km} / \mathrm{s}$ and $3.9 \mathrm{~km} / \mathrm{s}$, respectively) across the profile.

The Moho depth is 34 to $37 \mathrm{~km}$ (Fig. 7a). The deepest portion of the Moho is located in the middle of the profile at a model distance between 90 and $120 \mathrm{~km}$, and the Moho is shallowest in the east $(\sim 34 \mathrm{~km})$. We record only one upper mantle refraction phase Pn (SP2, Fig. 3d) with an apparent velocity of $8.0 \mathrm{~km} / \mathrm{s}$, with the velocity of the corresponding $\mathrm{Sn}$ phase being $4.5 \mathrm{~km} / \mathrm{s}$.

\section{Crustal composition}

Poisson's ratio is well correlated with the composition of the continental crust (Holbrook et al. 1992; Christensen and Mooney 1995; Christensen 1996; Musacchio et al. 1997; Swenson et al. 2000; Wang et al. 2003; Liu et al. 2006). We infer the crustal composition along our seismic profile using the relationship between Poisson's ratio and P-wave velocity. Plots of Poisson's ratio versus $V p$ (Fig. 13) show that the upper and middle crust mainly consists of felsic rocks, and the lower crust consists of rocks with an intermediate composition. Mafic compositions may be present in limited amounts, but do not dominate the crustal composition based on the relatively low P-wave velocities (Fig. 13).

In the upper crust, the relationship between Poisson's ratio and P-wave velocity is consistent with felsic rocks such as felsic gneiss and intermediate-to-high-grade metapelitic rocks. Rocks with $55 \%$ to $75 \% \mathrm{SiO}_{2}$ show a linear increase in Poisson's ratio with decreasing silica content, whereas P-wave velocity decreases and shear wave velocity increases with increasing percentages of $\mathrm{SiO}_{2}$ (Christensen 1996). The low Poisson's ratio at the surface along the eastern end of the profile (distance $120-220 \mathrm{~km})$ is due to the sedimentary cover. The Poisson's ratio $(\sim 0.25)$ and P-wave velocity $(\sim 6.1 \mathrm{~km} / \mathrm{s})$ in the upper crust (model distance $120-220 \mathrm{~km}$ at $5-12 \mathrm{~km}$ depth) is indicative of felsic rocks with a high quartz content, consistent with surface lithology (King and Beikman 1974; Glover and Klitgord 1995). The LVZ (model distance $0-100 \mathrm{~km}$ at $10-12 \mathrm{~km}$ depth) spatially corresponds to a body of metagraywacke, which has a $V p$ of $5.95 \mathrm{~km} / \mathrm{s}$ and a Poisson's ratio of 0.247 at a pressure of $400 \mathrm{MPa}$ (Christensen 1996).

The middle crust has a relatively uniform Poisson's ratio of 0.26 and an average $P$-wave velocity of $6.6 \mathrm{~km} / \mathrm{s}$, which is consistent with a dioritic composition (Christensen and Mooney 1995; Christensen 1996). Poisson's ratio in the lower crust is about 0.25 with an average 

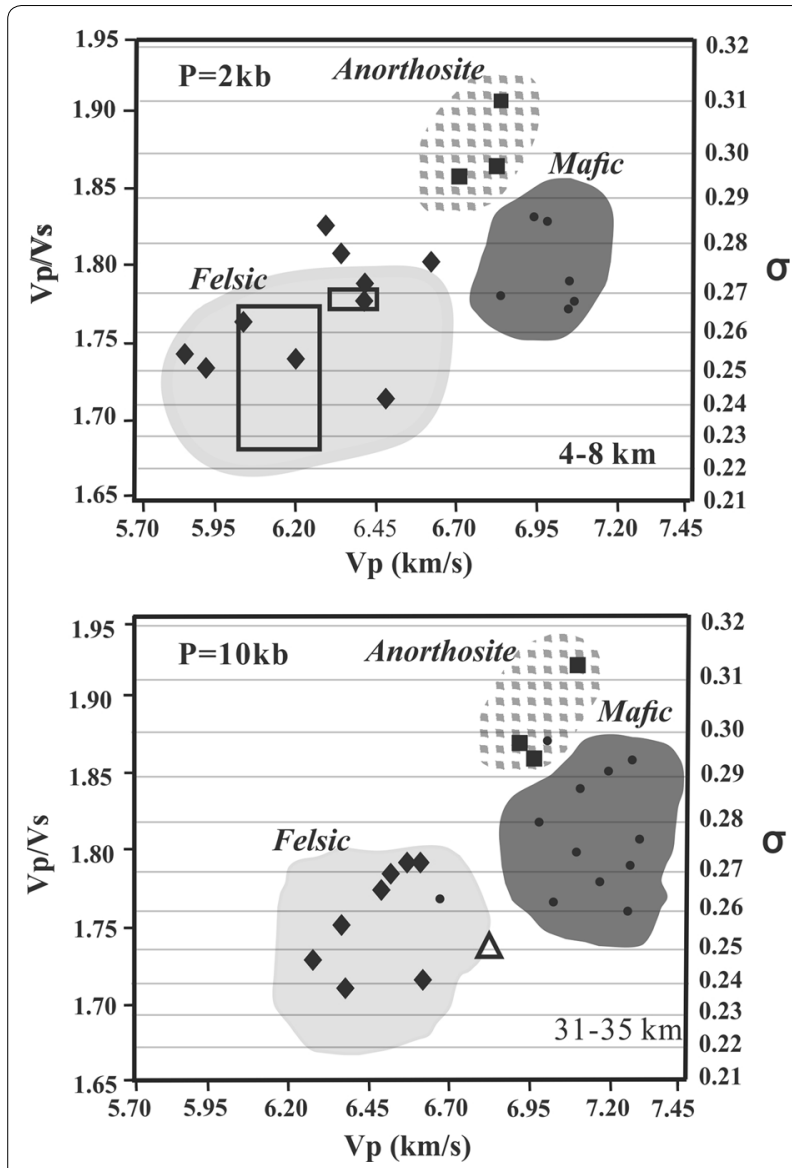

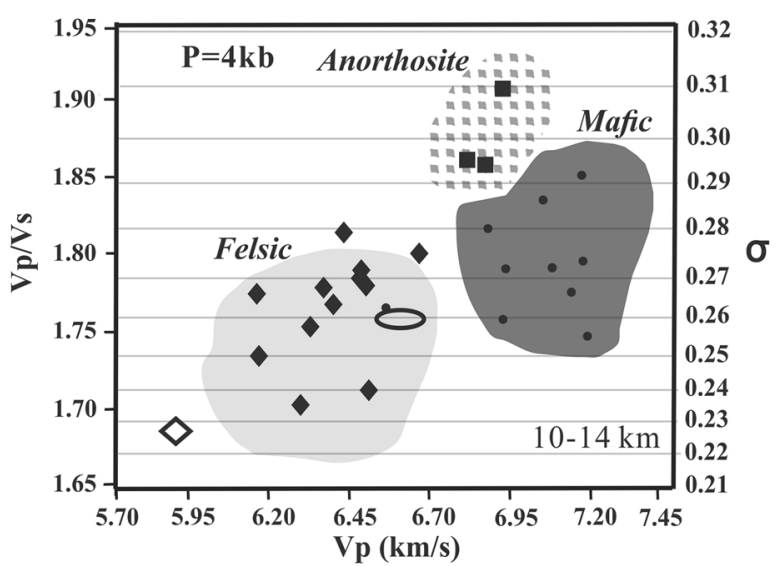

Anorthosite

Felsc rocks (greenschist-to-amphibolite facies) - Mafic rocks (granulite facies)

This study:

$\diamond$ Low velocity zone

$\square$ Upper crust

Middle crust

$\triangle$ Lower crust

Fig. $13 \mathrm{Vp} / \mathrm{Vs}$ and Poisson's ratio $\sigma$ versus $V p$ at pressures characteristic for 4 to $8 \mathrm{~km}$ depth (2 kb), 10 to $14 \mathrm{~km}$ depth (4 kb), and 31 to $35 \mathrm{~km}$ depth $(10 \mathrm{~kb})$, based on Musacchio et al. (1997). Solid symbols indicate laboratory measurements on rock samples. Gray-shaded areas indicate domains of felsic, mafic, and anorthosite composite as derived from laboratory measurement. Open symbols indicate values obtained from the Line 1 seismic profile (this study)

velocity of $6.85 \mathrm{~km} / \mathrm{s}$, consistent with intermediate composition metamorphic rocks (Fig. 13). Significantly, our seismic model shows no evidence for a mafic lower crustal layer having a P-wave seismic velocity $>6.9 \mathrm{~km}$ and a Poisson's ratio $\geq 0.28$. Hence, there is no evidence for mafic underplating beneath the Line 1 seismic profile.

\section{Tectonic interpretation}

Figure 14 shows the results of three studies of crustal structure in the study area. Figure 14a shows a seismic reflection profile in the Blue Ridge, a piedmont of the Appalachian orogeny (line $\mathrm{A}-\mathrm{A}^{\prime}$ in Fig. 1, Pratt et al. 1988, 2014). Figure 14b shows the crustal model of the western margin of the Atlantic Ocean (line E-E' in Fig. 1, Holbrook et al. 1994), and Fig. 14c shows the eastern Piedmont and coastal plain model of Line 1 seismic profile (our study).

\section{Continental crustal structure}

The Line 1 model shows a laterally homogenous crustal structure beneath the coastal plain; there are only slight horizontal variations in both velocity and boundary depths. In the west, the boundaries are consistent with the structure of Line A-A' (Fig. 14a, Pratt et al. 1988, 2014). The upper crustal velocity model of the western end of Line 1 (Fig. 14c) is relatively simple, with an upper crustal LVZ, beneath the Piedmont. However, a more complex image is seen in the vertical-incidence seismic reflection profile (Fig. 14a, Pratt et al. 1988, 2014). The reflection profile shows dipping structures within the upper crust. In the middle and lower crust, the seismic reflection section (Fig. 14a) is much more transparent, consistent with the uniform seismic velocity structure determined on the Line 1 seismic refraction/wide-angle reflection profile (Fig. 14c).

At the eastern end of our profile, the seismic velocity structure is in agreement with the seismic velocity values 

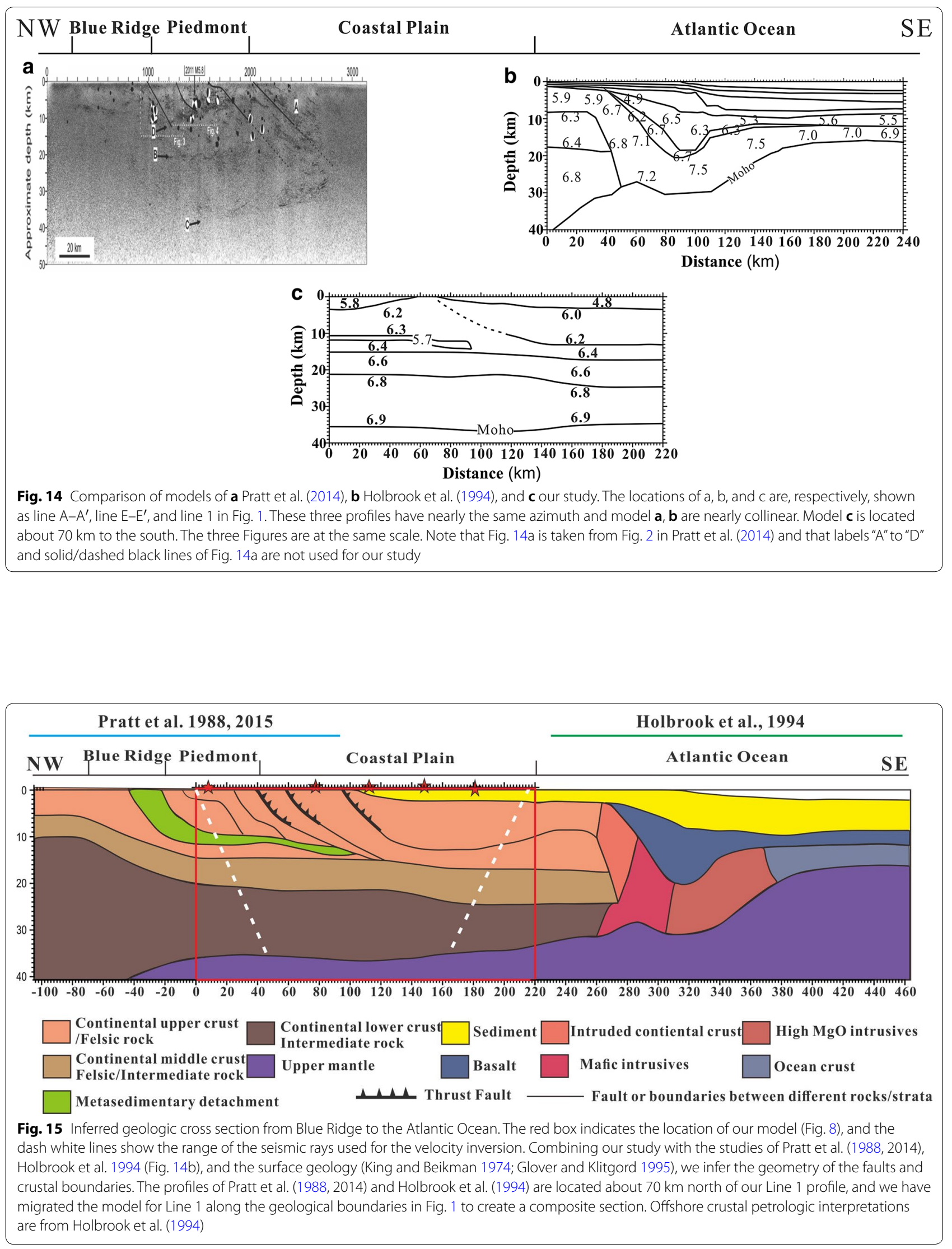
and boundary depths for the west end of the seismic line presented by Holbrook et al. (1994) (Fig. 14b). We divided the lower crust of Holbrook et al. (1994) into middle $(\sim 6.4 \mathrm{~km} / \mathrm{s})$ and a lower $(\sim 6.8 \mathrm{~km} / \mathrm{s})$ crust. The estimated Moho depths on the west end of Fig. $14 \mathrm{~b}(\sim 42 \mathrm{~km}$ is unconstrained by seismic coverage; Line 1 (Fig. 14c) indicates a value of $\sim 34 \mathrm{~km}$ (Holbrook et al. 1994).

Figure 15 shows a composite crustal section derived from the three seismic profiles in Fig. 13. This crustal section extends from the Blue Ridge Province of the Appalachians to the Atlantic Ocean basin. We infer that the upper crustal LVZ (green layer, Fig. 15) is an over-thrust metasedimentary layer based on the P-wave velocity and Poisson's ratio, and we infer the LVZ is the Evington Group metasedimentary rocks reaching depths of up to $10 \mathrm{~km}$ (Pratt et al. 1988). Also, it is associated with the metasedimentary strata of Paleozoic age beneath the coastal plain in Georgia, which is a result of ocean-basin closures (Cook et al. 1979, 1981). The faults in the Piedmont do not appear to cut through the LVZ, and the faults in the coastal plain do not extend to more than $15 \mathrm{~km}$ depth.

Overall, it appears that the Grenville-aged lower crust is thinned, extending beneath the Appalachian orogeny to the Atlantic Ocean (Fig. 15). The western edge of the ocean-continent transition is located $40 \mathrm{~km}$ east of Line 1 , and oceanic crust $160 \mathrm{~km}$ to the east (Fig. 15).

\section{Rifting margin}

Figure 16 presents the locations of our study and the two other rifts that are used for comparison. The eastern North American margin (ENAM), the region of our study, initiated in the early Mesozoic following the culmination of the Appalachian orogeny. The South China Sea (SCS) rift developed in the Cenozoic, accompanied by massive volcanic activity that is hypothesized to be due to a rollback of the subducting Paleo-Pacific slab beginning in the Middle Jurassic (Wan et al. 2017). The Cenozoic Kenya Rift, part of the eastern branch of the East African Rift System, has developed in an area of great lithospheric complexity (Macdonald et al. 1994) related to late Proterozoic orogenic events. The modern rift may be due to both active and passive mechanisms (Macdonald et al. 1994). Each of these rifts has experienced a unique extensional history, and the comparison reveals the relationship between crustal structure and tectonic evolution.

The similar feature of these three crustal structures is the velocity structure of the upper $(6.0-6.4 \mathrm{~km} / \mathrm{s})$, middle $(6.5-6.6 \mathrm{~km} / \mathrm{s})$, and lower $(6.7-6.9 \mathrm{~km} / \mathrm{s})$ crust (Zhang et al. 2013; Wan et al. 2017; Maguire et al. 1994; Braile et al. 1994) along with the upper mantle velocity $(7.9-8.0 \mathrm{~km} / \mathrm{s})$ (Figs. 14, 17). One notable feature of the three models is the high-velocity zone (HVZ, 7.0$7.6 \mathrm{~km} / \mathrm{s}$ ) intruding into the crust. The HVZ of the SCS rift is a 6-km-thick basal layer extending at least $160 \mathrm{~km}$, underplating much of the offshore lower crust (Wan et al. 2017). In contrast, the HVZ magmatic intrusion of the ENAM is focused within a $100-\mathrm{km}$-wide zone at the ocean-continent transition (Holbrook et al. 1994). This HVZ may have formed when the rifting extension rate suddenly speeded up (Brune et al. 2016). The large underplated area (high seismic velocity) at the bottom of the SCS rift crust may be associated with a smooth variation

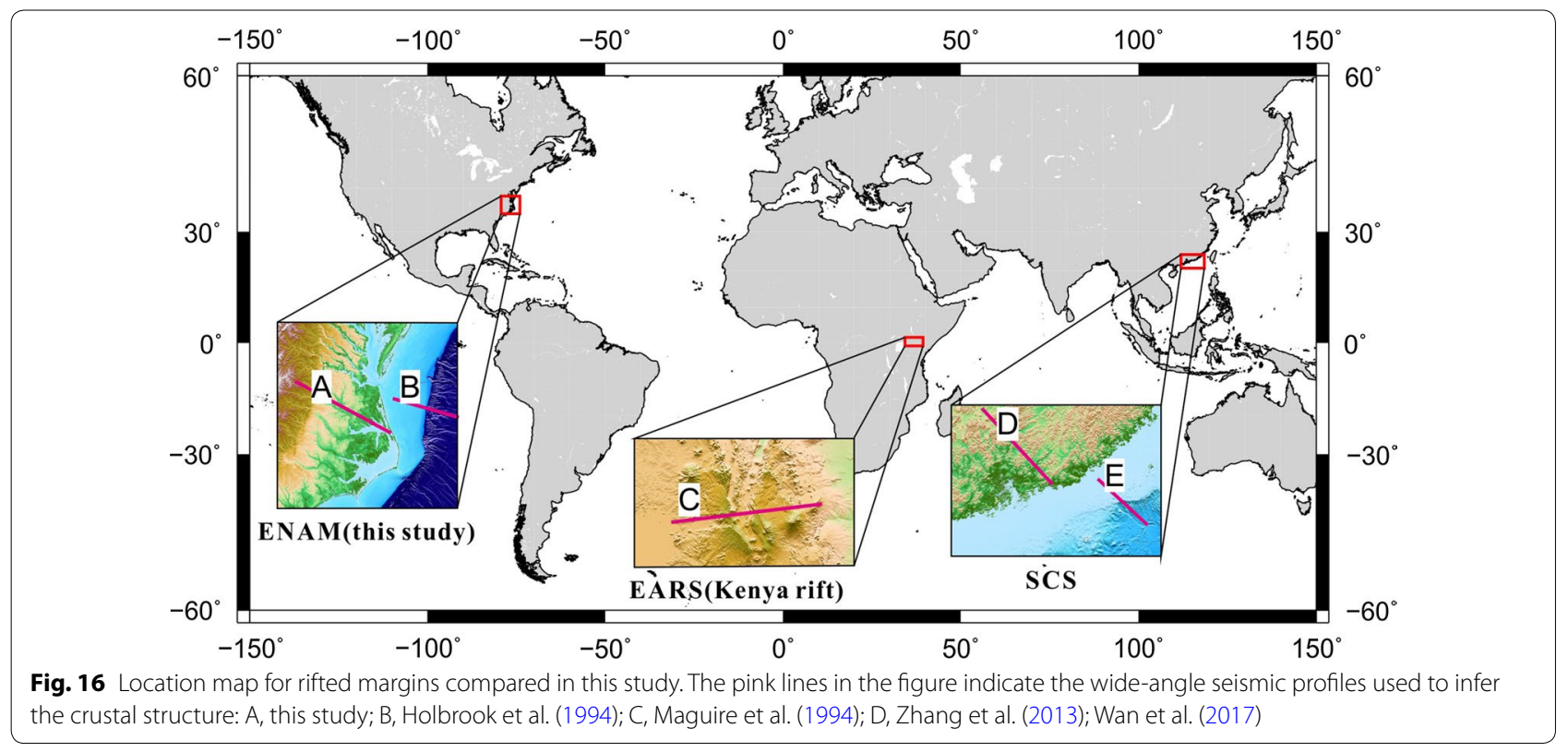




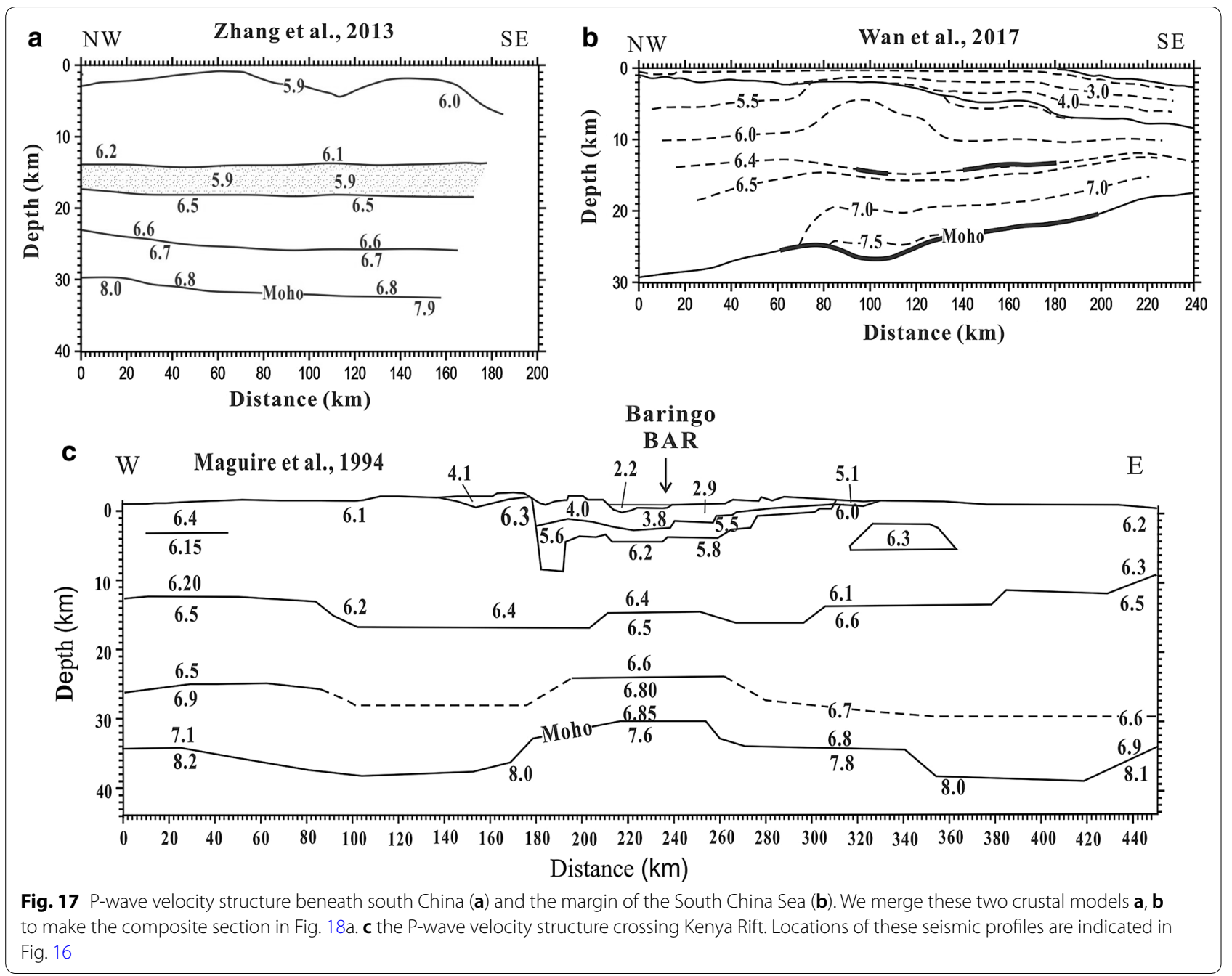

of rift-related extension during the breakup (Brune et al. 2016). Since the duration of the breakup process of the ENAM and the SCS rift are about 10 Myr (Brune et al. 2016), the different characteristic of narrow and wide rift may be associated with variations in the rate of extension of the rifted margin during the breakup. The HVZ of the Kenya Rift is limited to a width of only $100 \mathrm{~km}$ at the top of the upper mantle. This HVZ region may have been formed during two distinct stages of rapid cooling from $\sim 65$ to $45 \mathrm{Ma}$ and from $\sim 15 \mathrm{Ma}$ to the present day during the rift development (Torres Acosta et al. 2015). It seems that the formation of the limited basal crustal HVZ in narrow rifts is related to the sharp variations in the extension history.

Lateral variations in crustal thickness are features that can be used to characterize rift type. For example, narrow rifts may show large lateral gradients in crustal thickness, while wide rifts are characterized by small lateral gradients (Buck 1991). The ENAM onshore extended crustal thickness is $33-37 \mathrm{~km}$ and thins to about $30 \mathrm{~km}$ at the ocean-continent transition zone at a distance of $260 \mathrm{~km}$ (Figs. 15, 18b). The middle and lower crust extend only as far east as the rifted zone, where they terminate. The offshore ocean-continent transition is $100 \mathrm{~km}$ wide, with normal oceanic crust beginning immediately to the east (Holbrook et al. 1994; Lynner and Porritt 2017). Beneath the profiles in the SCS rift, there is no distinct oceancontinent transition as seen on the mid-Atlantic margin, and the extended crust is extended from continent to the ocean. The onshore extended continental crust is $220 \mathrm{~km}$ long with a small crustal thickness variation $(30-32 \mathrm{~km})$, while the offshore extended crust thins from 30 to $16 \mathrm{~km}$ (excluding the water column) over a lateral distance of $240 \mathrm{~km}$ (Wan et al. 2017). These observations suggest a greater amount of crustal extension is present on the SCS profile as compared to the onshore mid-Atlantic Margin. The crustal thickness of the Kenya Rift is $31-38$ km over a lateral distance of $220 \mathrm{~km}$, with the area of greatest crust 


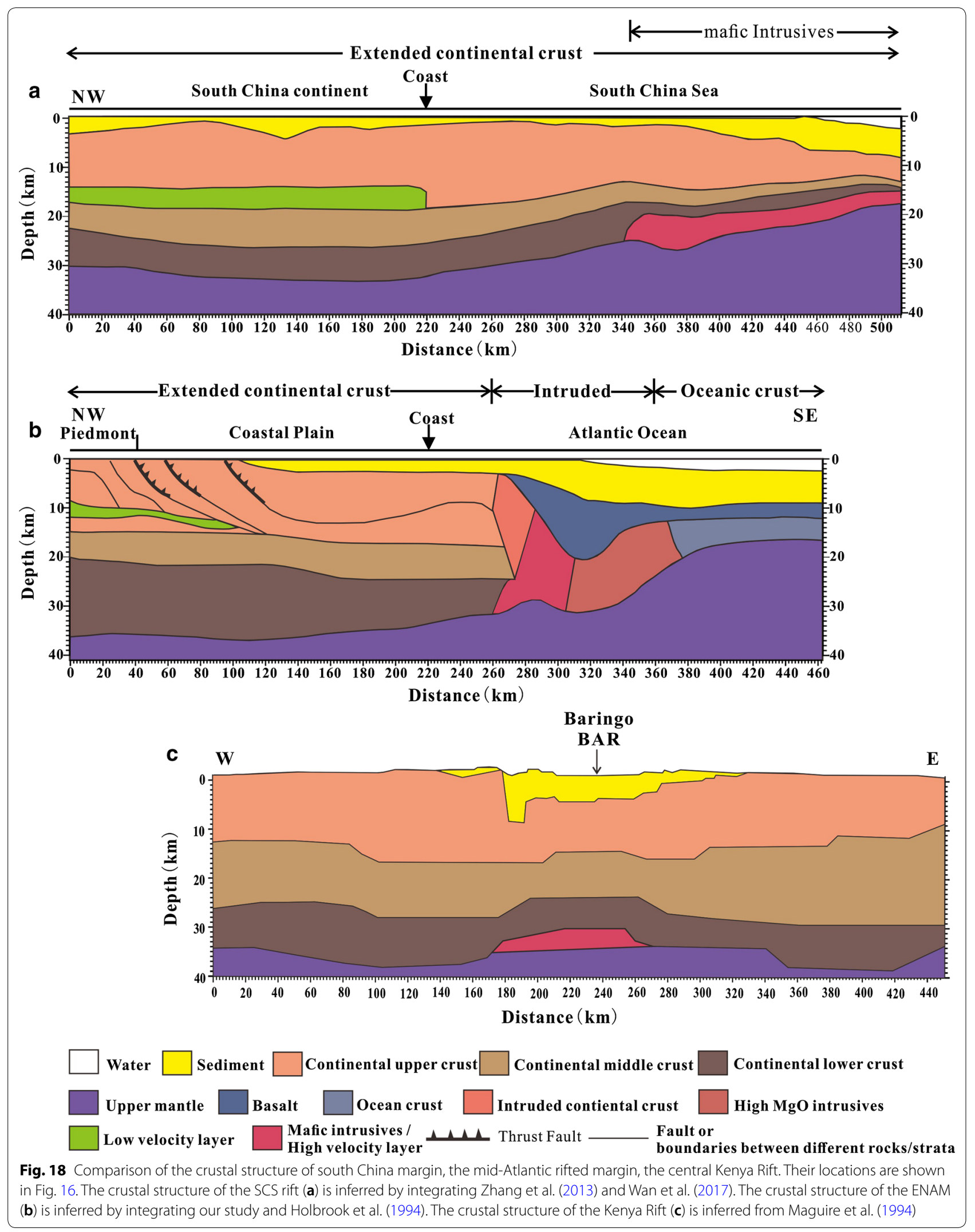


thinning (ca. $6 \mathrm{~km}$ ) directly beneath the $5 \mathrm{~km}$-deep rift basin. The flanking crust of the Kenya Rift has not been significantly modified by magmatic intrusion, in agreement with the mid-Atlantic coastal plain (this study). This observation indicates that both the ENAM and the Kenya Rift have the characteristics of a narrow rift, while the south China margin is an example of a widerifted margin (Wan et al. 2017). We hypothesize that the differences in 2D crustal structure for narrow and wide rifts is associated with the different extensional rates during continental breakup. ENAM and the Kenya Rift have similar crustal structure, and it appears that the Kenya Rift could eventually develop a similar crustal architecture as the mature mid-Atlantic rifted margin.

\section{Conclusions}

We present the crustal P- and S- wave velocity, Poisson's ratio, and density structure along the seismic wide-angle profile across the mid-Atlantic continent margin. The crustal thickness in the study area varies only slightly, from 34 to $37 \mathrm{~km}$. The thickest crust of 37 occurs beneath the coastal plain. Excluding the sedimentary cover that reaches $\sim 4 \mathrm{~km}$ thick in places, the crystalline crust thins to about $30 \mathrm{~km}$ at the Atlantic coast, indicating only a modest amount (19\%) of differential crustal extension (from 37 to $30 \mathrm{~km}$ ) along the profile. There is a seismic low-velocity zone at depth of $10-12 \mathrm{~km}$ beneath the eastern Piedmont and western coastal plain. We interpret this to be an over-thrusted package of Paleozoic sedimentary and metamorphic rocks, a result of oceanbasin closure during the Appalachian orogeny. The laterally uniform middle and lower crustal can be traced from beneath the eastern Piedmont across the Atlantic coastal plain, which indicates that Grenville-aged crust extends east to the western edge of the offshore rifted margin.

The measured P-wave velocities and Poisson's ratio indicate that the upper and middle crust both have a felsic composition, while the lower crust has an intermediate composition. There is no evidence for a mafic lower crustal layer with a high $(>6.9 \mathrm{~km} / \mathrm{s})$ seismic velocity or high $(>0.28)$ Poisson's ratio beneath our seismic profile. Thus, there is no evidence for a mafic underplated lower crustal layer that can be attributed to the offshore Mesozoic rifting. Integrated with previous research in the eastern North American margin, a broad view of the rifted continental margin shows that the Mesozoic rifting was focused in a 100-km-wide ocean-continent transition zone (east of our seismic profile), which is a characteristic of narrow-rifted margins.

We have compared our results with the crustal structure of the South China Sea rift and Kenya Rift. The crustal structure of the Kenya Rift within the East
African Rift System is more similar to the eastern North American margin than the South China Sea rift. The ENAM and the Kenya Rift are narrow rifts, whereas the South China Sea rift is a wide rift. The comparison indicates that narrow and wide rifts have similar crustal compositions, but show differences in lateral variations in crustal thickness and the distribution of basal crustal mafic intrusions. This difference may be associated with rifting extension rate. Further comparisons among global rifted margins are needed to support this hypothesis.

\section{Additional file}

Additional file 1. Supporting information for the crustal structure of the Atlantic Coastal Plain in North Carolina and Virginia, Eastern North American Margin.

\section{Abbreviations}

LVZ: low-velocity zone; ENAM: the eastern North American margin; USGS: United States Geological Survey; NMO: normal moveout; SCS: South China Sea; HVZ: high-velocity zone.

\section{Acknowledgements}

The collection of these data was coordinated by Southern Methodist University and the Woods Hole Oceanographic Institution. We are grateful to the dedicated twenty-person field crew and two IRIS-PASSCAL technicians who participated in the field. Seismic sources were coordinated by S. Harder and others from UT-El Paso. Discussions with numerous geologists, including R. Hatcher, K. Farrell, and C. Hughes, improved our understanding of the local geology. R. Blakely provided gravity data (https://mrdata.usgs.gov/gravity/ bouguer). W.-B. Guo gratefully acknowledges financial support from Chinese Scholarship Council.

\section{Authors' contributions}

W.G. led this study and drafted the manuscript. S.Z. did the data processing. F.W., Z.Y., S.J., and Z.L. improved the data processing and interpretation. All authors read and approved the final manuscript.

\section{Funding}

This study was funded by National Science Foundation GeoPRISMS Program, National Natural Science Foundation of China (41674068,41474075, 41774072), and China Earthquake Science Experiment (2016CESE0103), and the software used in identification of the seismic phases is supported by Science for Earthquake Resilience of China (XH16050Y).

\section{Availability of data and materials}

The seismic data used are available from the NSF IRIS Data Management Center (www.iris.edu/ds/nodes/dmc). R. Blakely provided gravity data (https:// mrdata.usgs.gov/gravity/bouguer).

Ethics approval and consent to participate

Not applicable.

\section{Consent for publication}

Not applicable.

Competing interests

The authors declare that they have no competing interests. 


\section{Author details}

${ }^{1}$ Geophysical Exploration Center, China Earthquake Administration, Zhengzhou, China. ${ }^{2}$ Beijing Earthquake Administration, Beijing, China.

Received: 12 April 2019 Accepted: 8 June 2019

Published online: 20 June 2019

\section{References}

Anderson ED, Moecher DP (2009) Formation of high-pressure metabasites in the southern Appalachian Blue Ridge via Taconic continental subduction beneath the Laurentian margin. Tectonics 28(5):1-27

Bezada MJ, Magnani MB, Zelt CA, Schmitz M, Levander A (2010) The Caribbean-South American plate boundary at $65^{\circ} \mathrm{W}$ : results from wide-angle seismic data. J Geophys Res. https://doi.org/10.1029/2009JB007070

Bonini WE, Woollard GP (1960) Subsurface geology of North Carolina-South Carolina coastal plain from seismic data. AAPG Bull 44(3):298-315

Braile LW, Smith RB (1975) Guide to the interpretation of crustal refraction profiles. Geophys J Roy Astron Soc 40(2):145-176. https://doi.org/10.1111/ j.1365-246X.1975.tb07044.X

Braile LW, Wang B, Daudt CR, Keller GR, Patel JP (1994) Modeling the 2D seismic velocity structure across the Kenya rift. Tectonophysics 236:251-269

Brocher TM (2005) Empirical relations between elastic wavespeeds and density in the earth's crust. Bull Seismol Soc Am 95(6):2081-2092. https://doi. org/10.1785/0120050077

Brune S, Williams SE, Butterworth NP, Müller RD (2016) Abrupt plate accelerations shape rifted continental margins. Nature 536(7615):201-204. https ://doi.org/10.1038/nature18319

Buck WR (1991) Modes of continental lithospheric extension. J Geophys Res Solid Earth 96(B12):20161-20178. https://doi.org/10.1029/91JB01485

Cady JW (1980) Calculation of gravity and magnetic anomalies of finite-length right polygonal prisms. Geophysics 45(10):1507-1512

Christensen NI (1996) Poisson's ratio and crustal seismology. J Geophys Res 101(B2):3139-3156. https://doi.org/10.1029/95JB03446

Christensen NI, Mooney WD (1995) Seismic velocity structure and composition of the continental crust: a global review. J Geophys Res 100(B6):9761-9788

Cook FA, Albaugh DS, Brown LD, Kaufman S, Oliver JE, Hatcher RD (1979) Thin-skinned tectonics in the crystalline southern Appalachians; COCORP seismic-reflection profiling of the Blue Ridge and Piedmont. Geology 7(12):563-567

Cook FA, Brown LD, Kaufman S, Oliver JE, Petersen TA (1981) COCORP seismic profiling of the Appalachian orogen beneath the Coastal Plain of Georgia. GSA Bull 92(10):738-748

Delescluse M, FunckT, Dehler SA, Louden KE, Watremez L (2015) The oceanic crustal structure at the extinct, slow to ultraslow Labrador Sea spreading center. J Geophys Res Solid Earth 120:5249-5272. https://doi. org/10.1002/2014JB011739

Dreiling J, Mooney WD (2015) Shear-wave velocity structure and attenuation derived from aftershock data of the 2011 Mineral, Virginia, earthquake. In: Horton JW Jr., Chapman MC, RA Green (eds) The 2011 Mineral, Virginia, earthquake and its significance for seismic hazards in Eastern North America, in Geological Society of America Special Paper, vol 509. https:// doi.org/10.1130/2015.2509(05)

Ebinger CJ (1989) Tectonic development of the western branch of the East African rift system. Geol Soc Am Bull 101(7):885-903

Ettensohn FR (1985) The Catskill delta complex and the Acadian Orogeny: a model. In: Woodrow DL, Sevon WD (eds) The Catskill delta: Geological Society of America Special Paper, vol 201. GSA, Boulder, pp 39-49

Fuchs K, Müller G (1971) Computation of synthetic seismograms with the reflectivity method and comparison with observations. Geophys I Int 23(4):417-433

Giese P, Prodehl C, Stein A (1976) Explosion seismology in central Europe: data and results. Springer, Berlin

Glover L, Klitgord KD (1995) E-3 southwestern Pennsylvania to Baltimore Canyon Trough. Geological Society of America, Boulder

Hales AL, Helsley CE, Dowling JJ, Nation JB (1968) The east coast onshoreoffshore experiment. I. The first arrival phases. Bull Seismol Soc Am 58(3):757-819
Hartz EH, Torsvik TH (2002) Baltica upside down: a new plate tectonic model for Rodinia and the lapetus Ocean. Geology 30(3):255-258

Hatcher RD (2007) Tectonic map of the southern and central Appalachians: a tale of three orogens and a complete Wilson cycle. In: Hatcher RD (ed) 4-D framework of continental crust. Geological Society of America https ://doi.org/10.1130/2007.1200(29)

Holbrook WS, Mooney WD, Christensen NI (1992) The seismic velocity structure of the deep continental crust. In: Fountain DM, Arculus R, Kay RW (eds) Continental lower crust. Elsevier Science, New York, pp 1-43

Holbrook WS, Purdy GM, Sheridan RE, Glover L, Talwani M, Ewing J, Hutchinson D (1994) Seismic structure of the US Mid-Atlantic continental margin. J Geophys Res Solid Earth 99(B9):17871-17891. https://doi. org/10.1029/94jb00729

Hole JA, Zelt BC (1995) 3-D finite-difference reflection travel times. Geophys J Int 121(2):427-434

Hughes S, Luetgert JH, Christensen NI (1993) Reconciling deep seismic refraction and reflection data from the Grenvillian-Appalachian boundary in western New England. Tectonophysics 225(4):255-269

James DE, Smith TJ, Steinhart JS (1968) Crustal structure of the middle Atlantic states. J Geophys Res 73(6):1983-2007

Jia S, Wang F, Tian X, Duan Y, Zhang J, Liu B, Lin J (2014) Crustal structure and tectonic study of North China Craton from a long deep seismic sounding profile. Tectonophysics 627:48-56

King PB, Beikman HM (1974) Geologic map of the United States: U.S. Geological Survey, scale 1:2,500,000

Klitgord KD, Hutchinson DR, Schouten H (1988) US Atlantic continental margin; structural and tectonic framework. In: Sheridan RE, Grow JA (eds) The geology of North America, I-2, the Atlantic Continental Margin, U.S. Geological Society of America, Boulder, pp 19-55

Lawrence DP, Hoffman CW (1993) Geology of basement rocks beneath the North Carolina Coastal Plain. In: North Carolina Geological Survey Bulletin, vol 95

Lewis BT, Meyer RP (1977) Upper mantle velocities under the East Coast margin of the US. Geophys Res Lett 4(8):341-344

Liu M, Mooney WD, Li S, Okaya N, Detweiler S (2006) Crustal structure of the northeastern margin of the Tibetan plateau from the Songpan-Ganzi terrane to the Ordos basin. Tectonophysics 420(1-2):253-266

Luetgert JH, Mann CE, Klemperer SL (1987) Wide-angle deep crustal reflections in the northern Appalachians. Geophys J Int 89(1):183-188

Lynner C, Porritt RW (2017) Crustal structure across the eastern North American margin from ambient noise tomography: crustal structure ENAM. Geophys Res Lett 44(13):6651-6657. https://doi.org/10.1002/2017GL0735 00

Macdonald R, Williams LAJ, Gass IG (1994) Tectonomagmatic evolution of the Kenya rift valley: some geological perspectives. J Geol Soc 151(5):879888. https://doi.org/10.1144/gsjgs.151.5.0879

Maguire PKH, Swain CJ, Masotti R, Khan A (1994) A crustal and upper mantle cross-sectional model of the Kenya Rift derived from seismic and gravity data. Tectonophysics 236:217-249

Marillier F, Hall J, Hughes S, Louden K, Reid I, Roberts B, Clowes R, Coté T, Fowler J, Guest S, Lu J, Luetgert G, Quinlan C Spencer, Wright J (1994) LITHOPROBE East onshore-offshore seismic refraction survey - constraints on interpretation of reflection data in the Newfoundland Appalachians. Tectonophysics 232(1):43-58

Massey MA, Moecher DP (2005) Deformation and metamorphic history of the Western Blue Ridge-Eastern Blue Ridge terrane boundary, southern Appalachian Orogen. Tectonics 24(5):1-18

Musacchio G, Mooney WD, Luetgert JH, Christensen NI (1997) Composition of the crust in the Grenville and Appalachian Provinces of North America inferred from Vp/Ns ratios. J Geophys Res Solid Earth 102(B7):15225-15241

Olsen PE, Schlische RW, Gore PJW (1989) Tectonic, depositional, and paleoecological history of early Mesozoic rift basins, eastern North America. In: 28th international geology congress. Guidebook, AGU, Washington, pp $1-174$

Olsen PE, Schlische RW, Fedoshe MS (1996) 580 kyr duration of the Early Jurassic flood basalt event in eastern North America using Milankovitch cyclostratigrahpy. In: Morales M (ed) The continental Jurassic: transactions of the Continental Jurassic symposium, vol 60. Museum of Northern Arizona, Flagstaff, pp 11-22 
Pakiser LC, Mooney WD (1989) Geophysical framework of the continental United States, vol 172. Geological Society of America Memoir, Boulder

Park JO, Fujie G, Wijerathne L, Hori T, Kodaira S, Fukao Y et al (2010) A lowvelocity zone with weak reflectivity along the Nankai subduction zone. Geology 38(3):283-286

Pratt TL, Çoruh C, Costain JK, Glover L (1988) A geophysical study of the Earth's crust in central Virginia: implications for Appalachian crustal structure. J Geophys Res Solid Earth 93(B6):6649-6667

Pratt TL, Horton JW, Spears JW, Gilmer AK, McNamara DE (2014) The 2011 Virginia Mw 5.8 earthquake: Insights from seismic reflection imaging into the influence of older structures on eastern US seismicity. In: Horton JW Jr, Chapman MC, Green RA (eds) The 2011 Mineral, Virginia, earthquake, and its significance for seismic hazards in eastern North America, Geological Society of America Special Papers, vol 509. Boulder, GSA, pp 285-294

Sandmeier KJ, Wenzel F (1986) Synthetic seismograms for a complex crustal model. Geophys Res Lett 13(1):22-25

Shen W, Ritzwoller MH (2016) Crustal and uppermost mantle structure beneath the United States. J Geophys Res Solid Earth 121(6):1. https://doi. org/10.1002/2016jb012887

Sheridan RE, Musser DL, Glover L, Talwani M, Ewing Jl, Holbrook WS, Smithson S (1993) Deep seismic reflection data of EDGE US mid-Atlantic continental-margin experiment: implications for Appalachian sutures and Mesozoic rifting and magmatic underplating. Geology 21(6):563-567

Swenson JL, Beck SL, Zandt G (2000) Crustal structure of the Altiplano from broadband regional waveform modeling: implications for the composition of thick continental crust. J Geophys Res Solid Earth 105(B1):607-621

Talwani M, Worzel JL, Landisman M (1959) Rapid gravity computations for two-dimensional bodies with application to the Mendocino submarine fracture zone. J Geophys Res 64(1):49-59

Thomas WA (2006) Tectonic inheritance at a continental margin. GSA Today 16:4-11

Torres Acosta V, Bande A, Sobel ER, Parra M, Schildgen TF, Stuart F, Strecker MR (2015) Cenozoic extension in the Kenya Rift from low-temperature thermochronology: links to diachronous spatiotemporal evolution of rifting in East Africa: Cenozoic Rifting Kenya: Thermochronology. Tectonics 34(12):2367-2386. https://doi.org/10.1002/2015TC003949

Trehu AM, Klitgord KD, Sawyer DS, Buffler RT (1989) Atlantic and Gulf of Mexico continental margins. In: Pakiser LC, MooneyWD (eds), geophysical framework of the continental United States, Geological Society of America Memoir, vol 172. GSA, Boulder, pp 349-382

Wan K, Xia S, Cao J, Sun J, Xu H (2017) Deep seismic structure of the northeastern South China Sea: origin of a high-velocity layer in the lower crust: the nature of HVL in northeastern SCS. J Geophys Res Solid Earth 122(4):2831-2858. https://doi.org/10.1002/2016JB013481
Wang Y, Mooney WD, Yuan X, Coleman RG (2003) The crustal structure from the Altai Mountains to the Altyn Tagh fault, northwest China. J Geophys Res Solid Earth. https://doi.org/10.1029/2001jb000552

Watkins JS, Best DM, Murphy CN, Geddes WH (1985) An investigation of the Albemarle Sound gravity anomaly, northeastern North Carolina, southeastern Virginia, and adjacent continental shelf. Southeast Geol 26:67-80

White R, McKenzie D (1989) Magmatism at rift zones: the generation of volcanic continental margins and flood basalts. J Geophys Res 94:76857729. https://doi.org/10.1029/JB094iB06p07685

Withjack MO, Schlische RW, Olsen PE (1998) Diachronous rifting, drifting, and inversion on the passive margin of central eastern North America: an analog for other passive margins. AAPG Bull 82(5A):817-835

Withjack M, Schlische RW, Olsen P (2012) Development of the passive margin of eastern North America: Mesozoic rifting, igneous activity, and breakup. In: Regional Geology and Tectonics: Phanerozoic Rift Systems and Sedimentary Basins, vol 1, pp. 300-335

Zandt G, Ammon CJ (1995) Continental crust composition constrained by measurements of crustal Poisson's ratio. Nature 374(6518):152

Zelt CA (1999) Modelling strategies and model assessment for wide-angle seismic traveltime data. Geophys J Int 139(1):183-204. https://doi. org/10.1046/j.1365-246X.1999.00934.x

Zelt CA, Barton PJ (1998) Three-dimensional seismic refraction tomography: a comparison of two methods applied to data from the Faeroe Basin. J Geophys Res Solid Earth 103(B4):7187-7210

Zelt CA, Forsyth DA (1994) Modeling wide-angle seismic data for crustal structure: Southeastern Grenville Province. J Geophys Res Solid Earth 99(B6):11687-11704. https://doi.org/10.1029/93JB02764

Zelt CA, Smith RB (1992) Seismic traveltime inversion for 2-D crustal velocity structure. Geophys J Int 108(1):16-34

Zhang Z, Bai Z, Mooney W, Wang C, Chen X, Wang E, Chen X, Wang E, Teng J, Okaya N (2009) Crustal structure across the Three Gorges area of the Yangtze platform, central China, from seismic refraction/wideangle reflection data. Tectonophysics 475(3-4):423-437. https://doi. org/10.1016/j.tecto.2009.05.022

Zhang Z, Xu T, Zhao B, Badal J (2013) Systematic variations in seismic velocity and reflection in the crust of Cathaysia: new constraints on intraplate orogeny in the South China continent. Gondwana Res 24(3):902-917

\section{Publisher's Note}

Springer Nature remains neutral with regard to jurisdictional claims in published maps and institutional affiliations.

\section{Submit your manuscript to a SpringerOpen ${ }^{\circ}$ journal and benefit from:}

- Convenient online submission

- Rigorous peer review

- Open access: articles freely available online

- High visibility within the field

- Retaining the copyright to your article

Submit your next manuscript at springeropen.com 